University of Chicago Law School

Chicago Unbound

Public Law and Legal Theory Working Papers

Working Papers

2008

\title{
The New Wheel in the Federal Machine: From Sovereignty to Jurisdiction in the Early Republic
}

Alison LaCroix

Follow this and additional works at: https://chicagounbound.uchicago.edu/public_law_and_legal_theory

Part of the Law Commons

Chicago Unbound includes both works in progress and final versions of articles. Please be aware that a more recent version of this article may be available on Chicago Unbound, SSRN or elsewhere.

\section{Recommended Citation}

Alison LaCroix, "The New Wheel in the Federal Machine: From Sovereignty to Jurisdiction in the Early Republic" (University of Chicago Public Law \& Legal Theory Working Paper No. 197, 2008) available at http://papers.ssrn.com/sol3/papers.cfm?abstract_id=10

This Working Paper is brought to you for free and open access by the Working Papers at Chicago Unbound. It has been accepted for inclusion in Public Law and Legal Theory Working Papers by an authorized administrator of Chicago Unbound. For more information, please contact unbound@law.uchicago.edu. 


\title{
CHICAGO
}

PUblic LAW AND LegAL THEORY WORKING PAPER NO. 197

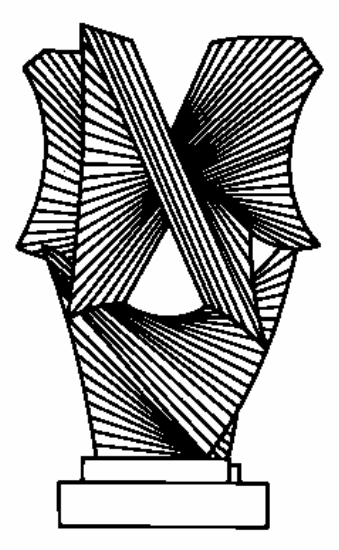

\section{THE NEW WHEEL IN THE FEDERAL MACHINE: FROM SOVEREIGNTY TO JURISDICTION IN THE EARLY REPUBLIC}

\author{
Alison L. LaCroix \\ THE LAW SCHOOL \\ THE UNIVERSITY OF CHICAGO
}

January 2008

This paper can be downloaded without charge at the Public Law and Legal Theory Working Paper

Series: http://www.law.uchicago.edu/academics/publiclaw/index.html and

The Social Science Research Network Electronic Paper Collection:

http://ssrn.com/abstract_id $=1085378$ 


\title{
The New Wheel in the Federal Machine: From Sovereignty to Jurisdiction in the Early Republic
}

\author{
Alison L. LaCroix ${ }^{*}$ \\ Draft - forthcoming, Supreme Court Review (2008)
}

The years between 1787 and 1802 witnessed a transformation in American federal theory: from the focus on legislative authority that had occupied constitutional thinkers since the colonial period to a new emphasis on jurisdiction and a corresponding institutional preoccupation with courts. This shift is evident in the decades-long debate concerning the nature and scope of the federal judicial power, which saw repeated efforts by jurists and statecrafters to establish the proper jurisdictional arrangement to mediate between the multiple levels of government set forth in the Constitution. The fruits of these struggles to cement the practical and ideological meanings of federalism were the judiciary acts of 1789 and 1801. The two acts have received remarkably disparate treatment from scholars, with the 1789 act heralded as the basis of the federal judicial system and the 1801 act largely regarded as an embarrassment notable only for its role in the partisan conflict surrounding the election of 1800.

Instead of lionizing the 1789 act and attempting to excuse or dismiss the 1801 act, however, I read the two together to offer new insights into these crucial decades. In the 1801 act, Federalists sought to revive the colonial idea of subject-matter jurisdiction by establishing broad federal jurisdiction, including granting "arising under" jurisdiction to the federal courts and easing the requirements for removal of cases from state to federal court. The election of 1800 and the ensuing repeal of the 1801 act, however, spelled the demise of this idea of jurisdiction and a return to the type of concurrence and overlap among levels of government that had characterized the system set up by the 1789 act. As a chapter in my forthcoming book on the history of the American federal idea, this essay challenges the assumption underlying some modern federalism scholarship that nationalization through the federal judiciary is a relatively new, post-1937 phenomenon. My argument demonstrates the anachronistic nature of such assumptions by highlighting the centrality of the judiciary to early republican debates concerning the scope and extent of national power.

\footnotetext{
* Alison L. LaCroix is Assistant Professor of Law, University of Chicago Law School. I am grateful to William Birdthistle and Adam Cox for their helpful comments and suggestions. I also thank the Elsie O. and Philip D. Sang Law Faculty Endowment and the Russell Baker Scholars Fund for research support.
} 
Legal historians and constitutional scholars have tended to approach the judiciary acts of 1789 and 1801 as though the two statutes were separated not only by a dozen years but also by a fundamental, unbridgeable conceptual gulf. While the Judiciary Act of $1789^{1}$ is celebrated as "probably the most important and the most satisfactory Act ever passed by Congress,” as Justice Henry B. Brown hailed it in 1911, the Judiciary Act of $1801^{2}$ is frequently regarded as a forgettable relic of early national political squabbling. ${ }^{3}$ The storied heritage of the 1789 act began with its passage into law more than four months before the Supreme Court convened for its first session, and therefore well in advance of the date when the entire federal government can truly be said to have begun functioning; ${ }^{4}$ the 1801 act, in contrast, is remembered principally for a pair of controversial distinctions: first, creating the circuit courts to which President John Adams appointed the so-called "midnight judges" on the eve of his departure from office; and second, suffering repeal at the hands of the newly Republican Congress one year later, in the aftermath of the acrimonious election of 1800. As Kathryn Turner Preyer observed, "[A]wareness of the Act seems to have been kept alive chiefly because it must be summoned to serve as the cause of its own repeal in March 1802." ${ }^{5}$ If the 1789 act stands for the fulfillment of the "Madisonian compromise" reached at Philadelphia, in which the delegates agreed to postpone the divisive issue of inferior federal courts to the First Congress, the 1801 act represents the failure of compromise, when the first party system collided with unsettled questions regarding the structure of the federal judiciary. ${ }^{6}$

Clearly, the two acts have received quite disparate treatment over the course of the past two centuries. But this difference fails to take into account their meaning and context in light of their shared historical moment. Too often, each judiciary act has been treated as an isolated piece of legislation complete in itself rather than as an intellectual vestige of a particular moment in American legal and political discourse. But the acts have more to tell us than this. Considering the two acts as disjunctive and dichotomous

\footnotetext{
${ }^{1}$ An Act to Establish the Judicial Courts of the United States, Ch. 20, 1 Stat. 73 (1789) (Judiciary Act of 1789).

2 An Act to Provide for the More Convenient Organization of the Courts of the United States, 2 Stat. 89 (1801) (Judiciary Act of 1801) (repealed by Judiciary Act of 1802, 2 Stat. 132 (1802)).

${ }^{3}$ Henry B. Brown, The New Federal Judicial Code, 36 ABA Rep 339, 345 (1911), quoted in Charles Warren, New Light on the History of the Federal Judiciary Act of 1789, 37 Harv L Rev 49, 52 (1923).

${ }^{4}$ The first session of the Supreme Court - attended by only four of the six original justices - took place in New York on February 2, 1790. See Robert G. McCloskey, The American Supreme Court 1-2 (Chicago 4th ed. 2004).

${ }^{5}$ Kathryn Turner [Preyer], Federalist Policy and the Judiciary Act of 1801, 22 Wm \& Mary Q 3, 3 (3d ser., 1965). See also William E. Nelson, The Province of the Judiciary, 37 John Marshall L Rev 325, 336 (stating that "[t]he 1801 Act, as we know, was a failure").

${ }^{6}$ On the Madisonian compromise, see Martin H. Redish and Curtis E. Woods, Congressional Power to Control the Jurisdiction of Lower Federal Courts: A Critical Review and a New Synthesis, 124 U Pa L Rev 45, 52-56 (1975); Robert N. Clinton, A Mandatory View of Federal Court Jurisdiction: A Guided Quest for the Original Understanding of Article III, 132 U Pa L Rev 741, 763-764 (1984).
} 
overlooks the vital role that both statutes played in the development of American federalism. Instead of lionizing the 1789 act and attempting to excuse or dismiss the 1801 act, reading the two together offers new insights into the crucial decades between 1787 and 1802, when theorists and politicians struggled to give meaning to the Constitution's phrase, "the judicial power of the United States."

If one regards the years from 1787 to 1802 as a single period and then situates that period at the end of a larger sweep of Anglo-American constitutional ferment, the two judiciary acts take on new significance beyond simply completing the founding settlement. On this view, the importance of the acts lies beyond their immediate consequences for the balance between state and federal judicial power, or even for the broader question of the meaning of union at the dawn of the nineteenth century. Rather, the debate surrounding the judiciary acts implicates federal ideas in the broadest sense that is, the specifically late-eighteenth-century/early-nineteenth-century effort to bring together multiple levels of authority within a single government while maintaining lines of demarcation between the levels. In other words, the judiciary acts must be understood as important sites for the development of federal theory, not simply as component parts in the heroic story of the construction of the modern American republic.

The passage of the judiciary acts, then, should be examined in the context of the continuing development of American federal ideas as ideas in the early republican period. The acts of 1789 and 1801 are vital to the story of federalism because their passage signaled a shift from legislative-focused theorizing, which had characterized the years roughly between 1765 and 1787, to a new emphasis on the role of judicial power in establishing and delineating boundaries between the levels of authority within a multilayered polity. ${ }^{7}$ Some scholars have pointed out the significance of the acts, especially the 1789 act, for establishing the federal judiciary in the separation-of-powers framework. ${ }^{8}$ Other commentators have explored the institutional role of the courts, vis-àvis other actors such as Congress or the states, in maintaining (or, in some cases, confounding) the federal structure. ${ }^{9}$ Rather than focusing on judicial supremacy at either the horizontal level of separation-of-powers analysis or the vertical level of state-federal relations, however, my analysis seeks to situate the judiciary acts in the context of the Revolutionary and early republican struggles to construct a federal union that was more

\footnotetext{
${ }^{7}$ On the general shift in focus from legislatures to courts - especially by the Federalists - in the ratification period, see, for example, Nelson, 37 John Marshall L Rev at 340-49 (cited in note 5); Gordon S. Wood, The Creation of the American Republic, 1776-1787 at 537-38 (W.W. Norton 1969).

8 See, for example, Akhil Reed Amar, America's Constitution: A Biography 227-32 (Random House 2005); Wythe Holt, "To Establish Justice": Politics, the Judiciary Act of 1789, and the Invention of the Federal Courts, 1989 Duke LJ 1421.

${ }^{9}$ See, for example, Larry D. Kramer, The People Themselves: Popular Constitutionalism and Judicial Review (Oxford: 2004); Jesse H. Choper, Judicial Review and the National Political Process: A Functional Reconsideration of the Role of the Supreme Court 171-259 (Chicago 1980); Alexander M. Bickel, The Least Dangerous Branch: The Supreme Court at the Bar of Politics (Bobbs-Merrill 1962); Herbert Wechsler, The Political Safeguards of Federalism: The Rôle of the States in the Composition and Selection of the National Government, 54 Colum L Rev 543 (1954).
} 
centralized than the old Confederation but less unitary in its distribution of sovereignty than the British Empire. ${ }^{10}$ On this view, the judiciary acts should be understood not only as markers in the retrospective, modern narrative of how the United States came to have to courts that it now has, but as experiments in fleshing out the sometimes ill-defined scheme of federal government that had slowly been emerging in America since the 1760s.

The two acts must be seen on their own terms, as attempts by particular individuals to confront functional questions of governmental authority that more than two decades' worth of thought and debate had left unaddressed. The turn to the judiciary in 1789 represented a subtle but important departure from the prominent role that the legislature had played in the past several decades' theories of divided authority. AngloAmerican theorists of the pre- and post-Revolutionary eras had for the most part shared their metropolitan cousins' emphasis on the legislative power as the most significant player in the contemporary constitutional arrangement. Many Americans, however, declined to follow this theory to the conclusion that was increasingly gaining adherents in Britain, among them Sir William Blackstone: namely, that the legislature - specifically, Parliament - possessed complete and indivisible sovereign authority. ${ }^{11}$ Consequently, in the transatlantic debates of the 1760s and 1770s, Anglo-Americans began to articulate a vision of political authority that explored new methods of segmenting power among many levels of legislatures, rather than vesting power entirely in one supreme legislature. In so doing, they rejected the growing orthodoxy of domestic British constitutional theory as well as the broader applications of that theory to the British Empire. Not until 1787, however, did the demands of the constitution-drafting process impel American thinkers to put aside the legislative focus of their political heritage and begin experimenting with the judicial power as a key component of the federal arrangement. ${ }^{12}$

To be sure, by 1789, the notion that the judiciary might potentially play a specific, structural role in the architecture of the federal republic remained a highly contested idea. It would continue to be controversial for many years, as the rancor surrounding the 1801 act and its repeal would demonstrate. But the period beginning around 1789 differed

${ }^{10}$ On the role that theories of empire played in the early Republic, see Daniel J. Hulsebosch, Constituting Empire: New York and the Transformation of Constitutionalism in the Atlantic World, 1664-1830 at 203-58 (North Carolina 2005); Peter S. Onuf, Jefferson's Empire: The Language of American Nationhood 53-79 (Virginia 2000).

${ }^{11}$ In Blackstone's view, set forth in his Commentaries on the Laws of England of 1765-69, government required a "supreme, irresistible, absolute, uncontrolled authority ... in which the rights of sovereignty reside.” William Blackstone, 1 Commentaries *49. For Blackstone, that authority was Parliament, which he described as possessing "sovereign and uncontrolable authority in making, confirming, enlarging, restraining, abrogating, repealing, reviving, and expounding of laws, concerning matters of all possible denominations, ecclesiastical, or temporal, civil, military, maritime, or criminal.” Parliament could thus "do every thing that is not naturally impossible." Id.

${ }^{12}$ For a more extended discussion of the origins of American federalism in this period, see Alison L. LaCroix, A Well-Constructed Union: An Intellectual History of American Federalism, 1754-1800 (Ph.D. diss., Harvard University, 2007). 
from the colonial, Revolutionary, and ratification periods in at least one crucial respect. The final decade of the eighteenth century and the early decades of the nineteenth century witnessed a transformation from sovereignty to jurisdiction as the central organizing principle - and battlefield - of American federalism.

As I will demonstrate, pre- and postwar debates regarding the essential nature of sovereignty - an inquiry that had occupied political theorists since the early modern era slowly gave way in the early republican period to a search for the proper jurisdictional arrangement to mediate between the multiple levels of government contemplated in the Constitution. This quest to find the appropriate structural mechanisms to avoid the "solecism" of an imperium in imperio, or a government within a government, continued to haunt early republicans, just as it had plagued their predecessors during the Stamp Act crisis of the 1760s and the confrontations between colonial assemblies and royal governors of the 1770s. ${ }^{13}$ Yet although they employed this inherited vocabulary, theorists and politicians in the 1790s and 1800s conceived of their problem not in terms of locating the initial source of governmental authority but instead as a question of delineating the boundaries among the judicial bodies that would guide the exercise of that authority. This second-generation process sought to fill in gaps and decipher hints left by the Constitutional Convention. In so doing, early republican theorists seized on Article III and the Supremacy Clause to guide their efforts to establish institutions that would carry out the federal project. The goal of this project was to build a structure to support the federal aspirations of the Constitution. The material of this structure was a theory of federal jurisdiction.

My analysis examines the rise of jurisdiction as the defining element of American federalism. Beginning around 1789, the organization of the federal judiciary became the locus of debates concerning both the practical and the ideological meaning of federalism. Commentators as diverse as Alexander Hamilton, Thomas Jefferson, John Marshall, Theodore Sedgwick, Joseph Story, and St. George Tucker focused on jurisdiction as they hammered out their own working understandings of federalism and confronted those of their contemporaries. This account thus challenges the assumption underlying some modern federalism scholarship that nationalization through the federal judiciary is a relatively new, post-1937 phenomenon. My argument demonstrates the anachronistic nature of such assumptions by highlighting the centrality of the judiciary to the nation's earliest debates concerning the scope and extent of national power. To be sure, general federal question jurisdiction did not become a stable fixture of American law until 1875. That date does not mean, however, that for the previous eighty-six years any consensus

\footnotetext{
13 The "solecism" of imperium in imperio was a powerful rhetorical device invoked repeatedly throughout eighteenth-century Anglo-American debates. See, for example, Federalist 20 (Madison with Hamilton), in The Federalist 128-29 (Wesleyan 1961) (Jacob E. Cooke, ed) (describing "a sovereignty over sovereigns, a government over governments, a legislation for communities, as contradistinguished from individuals" as "a solecism in theory" and "in practice"). As Daniel Hulsebosch has demonstrated, the pejorative dated back at least to 1720, when Henry St. John, Viscount Bolingbroke, referred to imperium in imperio as a "Solecism in Politicks." Daniel J. Hulsebosch, Imperia in Imperio: The Multiple Constitutions of Empire in New York, 1750-1777, 16 Law and Hist Rev 319, 340 n.58 (1998), citing [Bolingbroke], The Country Journal, or the Craftsman, no. 172, October 18, 1729.
} 
had held that the scope of federal courts' jurisdiction was limited, and properly so. On the contrary: viewing the expansion of federal jurisdiction as purely a post-

Reconstruction or a twentieth-century phenomenon ignores important early republican antecedents to those later developments. The period between 1787 and 1802 witnessed a transformation in American constitutional discourse from the language of legislative power and sovereignty to that of judicial power and jurisdiction.

I. Defining the Judicial Power, 1787-1789.

\section{A. Background: Convention and Constitution.}

The period between 1789 and 1802 witnessed the increased salience of the judicial power in the ongoing American dialogue regarding the proper arrangement of the layers of governmental power in a federal republic. In order to see this subtle but fundamental transformation in early national modes of thought, we must in a sense undomesticate the judiciary acts by examining them outside the familiar tropes of, on the one hand, the state-versus-federal binary that often preoccupies American constitutional history, and, on the other hand, twentieth- and twenty-first-century debates concerning the scope of modern federal courts' jurisdiction. Without question, those debates are important, and they occupy a deservedly central place in constitutional law and federal courts scholarship. ${ }^{14}$ But in order to comprehend the judiciary acts' significance for the historical narrative of federalism's origins, a wider perspective is necessary. This perspective begins with an inquiry into the particular legal and political context in which the acts were created.

When the First Congress convened in April 1789, fifty-four of the congressmen and senators had recently served as members of the Constitutional Convention or of the state ratification conventions. ${ }^{15}$ As part of those earlier deliberations, the members would have been involved in discussions concerning two measures that emerged in the course of the debates at Philadelphia and that shaped the role of the judiciary in the new republic. Although the provisions had different aims, taken together they suggested that judicial institutions would feature prominently in the new government that was being cobbled together.

\footnotetext{
${ }^{14}$ The literature concerning Congress's power to regulate the scope of federal jurisdiction is enormous. The classic account is Henry M. Hart, Jr., The Power of Congress to Limit the Jurisdiction of Federal Courts: An Exercise in Dialectic, 66 Harv L Rev 1362 (1953). More recent analyses include John Harrison, The Power of Congress to Limit the Jurisdiction of Federal Courts and the Text of Article III, 64 U Chi L Rev 203 (1997); Akhil Reed Amar, The Two-Tiered Structure of the Judiciary Act of 1789, $138 \mathrm{U}$ Pa L Rev 1499 (1990); Akhil Reed Amar, A Neo-Federalist View of Article III: Separating the Two Tiers of Federal Jurisdiction, 65 BU L Rev 205 (1985); Clinton, 132 U Pa L Rev at 741 (cited in note 6); Gerald Gunther, Congressional Power to Curtail Federal Court Jurisdiction: An Opinionated Guide to the Ongoing Debate, 36 Stan L Rev 895 (1984).

15 Richard Morris, ed., Encyclopedia of American History 145 (Harper \& Row 6th ed 1982).
} 
The first such measure, the so-called "Madisonian compromise," consisted of a provision that "the National Legislature be empowered to institute inferior tribunals"; the measure was adopted by the convention on June 5,1787 , after substantial debate. ${ }^{16}$ It was in the nature of a compromise in that it staved off a motion by John Rutledge of South Carolina to delete all references to inferior federal courts from the draft constitution, but it did not go as far as mandating the establishment of inferior federal courts, as had been proposed in Edmund Randolph's Virginia Plan or South Carolinian Charles Pinckney's draft constitution. ${ }^{17}$ Instead, the compromise was incorporated into Article III, which vested the "judicial Power of the United States" in "one supreme Court, and in such inferior Courts as the Congress may from time to time establish.",18

In addition to the Madisonian compromise, which established the potential for but not the certainty of inferior federal courts, the delegates at Philadelphia and in the state ratifying conventions engaged in a related debate that concerned not the horizontal relationship between Congress and lower federal courts but instead the vertical interaction between the general government and the states. Madison and other delegates such as Pinckney and James Wilson of Pennsylvania feared that the states might continue the unruly and independent behavior that they had displayed throughout the 1780s. A government capable of accommodating multiple levels of authority had been many colonists' desideratum since the 1760s, but the reality of the 1780s forced observers to reconsider the structure of this multi-tiered polity. How might the state legislatures be checked in their rush to issue paper currency, pass debtor-relief laws, deny the provisions of the peace treaty with Britain, and otherwise follow state rather than larger, national interests? ${ }^{19}$

As his voluminous notes and correspondence before the convention and his comments on the floor at Philadelphia made clear, Madison believed that he had the answer: the Constitution should grant Congress the power to negative state laws "in all cases whatsoever" - or at least, as other delegates suggested, in situations where Congress deemed the state law in question “improper." ${ }^{20}$ In other words, Madison hoped

${ }^{16} 1$ The Records of the Federal Convention of 1787 at 125 (Yale 1966) (Max Farrand, ed). For classic articulations of the Madisonian compromise, see Redish and Woods, $124 \mathrm{U}$ Pa L Rev at 52-56 (cited in note 6); Clinton, $132 \mathrm{U}$ Pa L Rev at 763-764 (cited in note 6).

17 See 1 Records of the Federal Convention 104-05, 119, 124-25; 2 id at 45-46 (cited in note 16).

${ }^{18}$ US Const Art III, § 1, cl. 1.

${ }^{19}$ On the turmoil of the 1780s and its consequences for the drafting of the Constitution, see Wood, The Creation of the American Republic at 393-429 (cited in note 7).

${ }^{20}$ Madison had aired his proposal for the federal negative in letters to Thomas Jefferson, Edmund Randolph, and George Washington as early as March 1787. The negative was a central feature of the Virginia Plan, which Randolph proposed at an early meeting of the Philadelphia convention. It attracted little controversy or even notice until June 8, at which point Pinckney's motion to expand the scope of Congress's from negativing state laws "contravening in the opinion of the National Legislature the articles of Union" to cover laws that Congress simply deemed "improper" galvanized debate. See 1 Records of the Federal Convention 164-73, 2 id. 25-36 (cited in note 16). For Madison's letters, see 9 The Papers of 
to use the legislative power of the general government to quell the wayward lawmaking tendencies of the several states. After much discussion - including an impassioned defense by Madison, who regarded the negative as "absolutely necessary to a perfect system" - the proposal suffered a series of defeats, culminating in its rejection on July 17 by a vote of seven states to three. ${ }^{21}$ Despite the failure of the negative, however, many of Madison's fellow delegates appear to have agreed with his judgment that checks on the "centrifugal tendency of the States" were necessary to prevent them from "continually fly[ing] out of their proper orbits and destroy the order \& harmony of the political system."22 A mechanism had to be found by which the states might be both restrained from exploiting each other and coaxed into aligning their interests with those of the Union.

The mechanism that the delegates settled on was a bold statement of federal supremacy that emerged more or less simultaneously with the demise of the negative. ${ }^{23}$ Adopting the language of William Paterson's New Jersey Plan, the delegates drafted what became the Supremacy Clause of Article VI. ${ }^{24}$ In contrast to Madison's scheme, which had embraced a legislative solution to the problem of mediating between the levels of authority within the federal republic, the Supremacy Clause presented the judiciary as a potential site of intergovernmental ordering. In this way, the clause addressed Madison's twin goals, as he subsequently described them in a letter to Jefferson: " 1 . to prevent encroachments on the General authority. 2. to prevent instability and injustice in the legislation of the States." 25 By identifying "the Laws of the United States" as the "supreme Law of the Land," which would in turn bind the "Judges in every State," the clause spoke the language of court-made law. One reads the Supremacy Clause and thinks of the interpretation of law through processes of adjudication, not the creation of law through the legislative process.

James Madison 317, 369, 383 (Chicago 1975) (Robert Rutland et al., eds). On the federal negative, see LaCroix, A Well-Constructed Union at 217-83 (cited in note 12).

211 Records of the Federal Convention 164 (cited in note 16).

${ }^{22} 1$ id. at 165.

${ }^{23}$ The final vote on the negative took place on July 17, 1787; immediately thereafter, the delegates took up the provision that would become the Supremacy Clause. See 2 id. 28-29. See also Kramer, The People Themselves at 74-75 (cited in note 9); Jack N. Rakove, The Origins of Judicial Review: A Plea for New Contexts, 49 Stan L Rev 1031, 1046-47 (1997); Jack N. Rakove, Original Meanings: Politics and Ideas in the Making of the Constitution 82-83 (Vintage 1996); Lawrence Gene Sager, The Supreme Court, 1980 Term - Foreword: Constitutional Limitations on Congress' Authority to Regulate the Jurisdiction of the Federal Courts, 95 Harv L Rev 17, 46-47 (1981).

24 US Const Art VI cl 2 ("This Constitution, and the Laws of the United States which shall be made in Pursuance thereof; and all Treaties made, or which shall be made, under the Authority of the United States, shall be the supreme Law of the Land; and the Judges in every State shall be bound thereby, any Thing in the Constitution or Laws of any State to the Contrary notwithstanding.”).

2510 Papers of James Madison 209-10 (cited in note 20). 
The evidence suggests that at least some members of the founding generation believed that the shift from the negative to the Supremacy Clause as a key federalismenforcing mechanism meant that the Supreme Court very likely possessed the power to review actions by both state legislatures and state courts. ${ }^{26}$ During the convention, Thomas Jefferson, at that time serving as minister to the Court of Versailles, conveyed to Madison his dislike for the negative and suggested that courts rather than Congress might be charged with policing the states. The negative, Jefferson wrote, "proposes to mend a small hole by covering the whole garment." 27 He disapproved of vesting Congress with such a broad - and potentially open-ended - power. Would it not be preferable, Jefferson asked, to rely on a more elegant solution that required less apparatus? " $[\mathrm{A}] \mathrm{n}$ appeal from the state judicature to a federal court, in all cases where the act of the Confederation controled the question" would "be as effectual a remedy, \& exactly commensurate to the defect."28 For Jefferson, allowing an injured party to appeal from a state court to a federal court was preferable to building an ex ante system of legislative review into the Constitution.

On the floor of the convention, other delegates similarly assumed that the alternative to the negative was case-by-case review by courts. Arguing that including the negative in the Constitution would “disgust all the States,” New Yorker Gouverneur Morris articulated the judicial approach: "A law that ought to be negatived will be set aside in the Judiciary departmt. and if that security should fail; may be repealed by a Nationl. law." ${ }^{29}$ In other words, judicial review of state law and state-court decisions was at least a possibility for delegates to the convention and their contemporaries. ${ }^{30}$

${ }^{26}$ By “federalism-enforcing mechanism,” I mean federalism in the structural, mechanical sense that most concerned Madison: namely, the need to incorporate the states into the general government, and in so doing to move from a confederation - the early modern political philosophers' "system of states" - to a new species of federal republic in which the central government had some independent powers rather than acting merely as a shell for the states. The construction "system of states" is associated with the early modern theorist Samuel von Pufendorf. See Samuel von Pufendorf, The Law of Nature and Nations: or, a General System of the most Important Principles of Morality, Jurisprudence, and Politics, trans. Basil Kennet (London 5th ed: 1749) (1672), vol. II, bk. VII, ch. V, § XVIII, 682-83. The phrase “judicially enforced federalism” has been used in modern scholarship to refer to courts' acting on behalf of substantive federal values, including "limits on the power of the national government vis-à-vis the states." Larry D. Kramer, But When Exactly Was Judicially-Enforced Federalism “Born” in the First Place?, 22 Harv J L \& Pub Policy 123, 123 (1998). For the source of the related debate regarding the need for the federal government to protect federalism by acting on behalf of the states, see Wechsler, The Political Safeguards of Federalism, 54 Colum L Rev at 543 (cited in note 9). See also Gerald Leonard, Party as a "Political Safeguard of Federalism": Martin Van Buren and the Constitutional Theory of Party Politics, 54 Rutgers L Rev 221 (2001); Larry D. Kramer, Putting the Politics Back Into the Political Safeguards of Federalism, 100 Colum L Rev 215 (2000).

2710 Papers of James Madison 64 (cited in note 20).

28 Id.

292 Records of the Federal Convention 28 (cited in note 16).

30 Morris later commented that portions of Article III had intentionally been drafted (by him) to speak in somewhat oblique terms. "[C]onflicting opinions had been maintained with so much professional astuteness, that it became necessary to select phrasaes, which expressing my own notions would not alarm 
But this vision of the judicial power of the United States concerned only the Supreme Court. It said nothing about the lower federal courts that Congress might eventually choose to establish, and therefore it provided few definitive answers to the question what the full judicial power of the United States might look like. Explication of those issues awaited the First Congress, where the veterans of the ratification debates and their colleagues together took up the question that, among a host of divisive issues that had vexed the Constitutional Convention, had been postponed to be dealt with by the legislature.

In the nineteen months between the end of the convention and the first meeting of Congress, the subject of inferior federal courts had generated prolonged and intense discussion. During the ratification debates in the states, pamphlets and speeches had focused on the issue as one of the key sites of dispute between supporters and opponents of the new constitution. ${ }^{31}$ The fervor with which commentators attacked the question of the federal courts suggests that they regarded jurisdictional decisions as central to defining the new republic.

Indeed, the provisions of the Constitution concerning the judicial power gave rise to some of the most vehement disagreements between Federalists and Antifederalists. The establishment of the Supreme Court proved relatively uncontroversial. ${ }^{32}$ The prospect of an entirely new echelon of federal courts in addition to the Supreme Court, however, tested many observers’ deepest constitutional commitments. In Federalist No. 81, Alexander Hamilton argued that inferior federal courts ought to be viewed merely as ancillae of the Supreme Court and not as independent forces of consolidation. Calling the establishment of federal district courts "highly expedient and useful," Hamilton concluded that "[t]his plan appears to me at present the most eligible of any that could be

others, nor shock their selflove, and to the best of my recollection, this was the only part which passed without cavil.” Morris to Timothy Pickering, Dec. 22, 1814, 3 id at 420. By the nineteenth century, the notion that judicial review had been adopted in place of the negative was a commonplace, at least for some theorists. See, for example, Joseph Story, Commentaries on the Constitution of the United States 607 (Hilliard, Gray abr ed 1833) (describing the federal government's power to check state legislatures as "either a direct negative on the state laws, or an authority in the national courts to overrule such, as shall be manifestly in contravention to the constitution" and concluding that "[t]he latter course was thought by the convention to be preferable to the former; and it is, without question, by far the most acceptable to the states”). See also William E. Nelson, Changing Conceptions of Judicial Review: The Evolution of Constitutional Theory in the States, 1790-1860, 120 U Pa L Rev 1166 (1972).

31 Compare, for example, George Mason Fears the Power of the Federal Courts: What Will Be Left to he States?, in 2 The Debate on the Constitution: Federalist and Antifederalist Speeches, Articles, and Letters During the Struggle over Ratification, January to August 1788 at 720-29 (Library of America 1993) (Bernard Bailyn, ed), with John Marshall on the Fairness and Jurisdiction of the Federal Courts, in id. at 730-41.

32 See "Introduction: The Constitutional Origins of the Federal Judiciary," 4 The Documentary History of the Supreme Court of the United States, 1789-1800 at 10 (Columbia 1992) (Maeva Marcus, ed) (hereafter DHSC). 
adopted. ${ }^{33}$ A few weeks later, John Marshall offered Virginia's ratifying convention a practical argument for the new courts. "Does not every Gentleman here know, that the causes in our Courts are more numerous than they can decide, according to their present construction?" he asked. The future chief justice then exhorted his colleagues to "[l]ook at the dockets. You will find them crouded with suits, which the life of man will not see determined." 34

Yet strong voices such as that of Maryland's Luther Martin lambasted the plan. Permitting Congress to appoint inferior courts "would eventually absorb and swallow up the state judiciaries," Martin insisted, "by drawing all business from them to the courts of the general government, which the extensive and undefined powers, legislative and judicial, of which it is possessed, would easily enable it to do." ${ }^{35}$ George Mason of Virginia, meanwhile, feared potential expansion of federal power under Article III. "The inferior Courts are to be as numerous as Congress may think proper," he warned. "Read the second section, and contemplate attentively the jurisdiction of these Courts; and consider if there be any limits to it.",36

Controversy regarding the establishment of the inferior federal courts thus smoldered during the ratification period, with each side in the debate invoking the first sentence of Article III ("The judicial Power of the United States, shall be vested in one supreme Court, and in such inferior Courts as the Congress may from time to time ordain and establish.") as evidence of either Philadelphian prudence or consolidationist connivance. ${ }^{37}$ Few observers could have been surprised, then, when on April 7, 1789, the First Congress took up the issue as its first item of business. Throughout the spring and summer of 1789, public attention was fixed on Federal Hall in Wall Street. As Virginia congressman Alexander White commented in a letter to Madison: "At the inns on the road, I was surprised to find the knowledge which the landlords, and the country people who were at some of them, had acquired of the debates and proceedings of Congress., ${ }^{38}$

${ }^{33}$ Federalist 81 (Hamilton), in The Federalist 547-48 (cited in note 13).

342 The Debate on the Constitution at 732 (cited in note 31).

${ }^{35}$ Luther Martin's Letter on the Federal Convention of 1787 (The Genuine Information), 1 The Debates in the Several State Conventions on the Adoption of the Federal Constitution, as Recommended by the General Convention at Philadelphia, in 1787, Together With the Journal of the Federal Convention, Luther Martin's Letter, Yates's Minutes, Congressional Opinions, Virginia and Kentucky Resolutions of '98-'99, and Other Illustrations of the Constitution 370 (Washington 1836) (Jonathan Elliott, ed).

${ }^{36} 2$ The Debate on the Constitution 720 (cited in note 31).

${ }^{37}$ US Const Art III, § 1, cl 1.

${ }^{38}$ White to Madison, Aug. 17, 1789, in Warren, 37 Harv L Rev at 65 (cited in note 3). 


\section{B. The Judiciary Act of 1789 .}

The history of the 1789 act's drafting and passage is well known. ${ }^{39}$ A Senate committee comprising ten members (one from each state that had ratified the Constitution and sent senators by that point) produced a first version of the act, which the committee circulated to select attorneys and officials for comment during the summer of $1789 .{ }^{40}$ On July 17, the Senate approved the bill by a vote of fourteen to six. The House of Representatives, which had been occupied drafting the amendments that formed the basis of the Bill of Rights, took up the judiciary act on August 24. After extensive debate much of it concerning the propriety of establishing inferior federal courts at all - and the addition of fifty-two amendments, the House passed the bill on September 17 by a vote of thirty-seven to sixteen. House and Senate then conducted speedy negotiations regarding some of the amendments before sending the bill on to President Washington, who signed it into law on September 24.

The most important provisions of the act for our purposes centered on two structural aspects: the jurisdiction of the Supreme Court and the organization and powers of the inferior federal courts, which the act broke down into the two categories of district courts and circuit courts. ${ }^{41}$ As students of Marbury v Madison will recall, the act sought

${ }^{39}$ For a comprehensive discussion of the background to the act, see Maeva Marcus, ed., Origins of the Federal Judiciary: Essays on the Judiciary Act of 1789 (Oxford 1992); Warren, New Light on the History of the Judiciary Act of 1789, 37 Harv L Rev at 49 (cited in note 3). For the debates, see 1 The Debates and Proceedings in the Congress of the United States; with an Appendix, Containing Important State Papers and Public Documents , and all the Laws of a Public Nature; With a Copious Index (Annals of the Congress of the United States) (Gales and Seaton 1834) (hereafter Annals).

40 The ten senators were Oliver Ellsworth (Connecticut), William Paterson (New Jersey), Caleb Strong (Massachusetts), Richard Henry Lee (Virginia), Richard Bassett (Delaware), William Maclay (Pennsylvania), William Few (Georgia), Paine Wingate (New Hampshire), Charles Carroll (Maryland), and Ralph Izard (South Carolina). Marcus notes that of the ten, "six had been members of the Continental Congress; and five had been members of their state ratifying conventions" and that "[w]ith the exception of Lee and Maclay, all were Federalists.” Moreover, "[a]ll but Izard and Wingate had at least some legal training," although she describes only Ellsworth, Strong, and Paterson as having "extensive legal experience.” Ellsworth handled the majority of the drafting. 4 DHSC at 22-23 (cited in note 32). William Maclay's journal suggests that tempers among the committee members occasionally flared up amidst the intense efforts to produce a draft bill. On June 29, Maclay noted, "Attended at the Hall early. Sent my letters to the post-office; and now for the judiciary. I made a remark where Elsworth [sic] in his diction had varied from the Constitution. This vile bill is a child of his, and he defends it with the care of a parent, even with wrath and anger." William Maclay, Journal of William Maclay, United States Senator From Pennsylvania, 1789-1791 at 91 (D.A. Appleton 1890) (Edgar S. Maclay, ed).

41 At least as important, but beyond the scope of this Article, are two related issues on which modern commentators frequently look to the 1789 act: (1) the extent of Congress's power over inferior federal courts vis-à-vis the jurisdictional baseline set forth in Article III; and (2) the question of which law applies in federal diversity cases, and the corollary inquiry into the existence or nonexistence of a federal common law. On the former, see the sources cited in note 14 above. On the latter, see Tony Freyer, Harmony and Dissonance: The Swift and Erie Cases in American Federalism (NYU 1981); Julius Goebel Jr., Antecedents and Beginnings to 1801 at 229-30 (Macmillan 1971); Felix Frankfurter and James M. Landis, The Business of the Supreme Court: A Study of the Federal Judicial System (Macmillan 1927); Warren, New Light on the History of the Judiciary Act of 1789, 37 Harv L Rev at 49 (cited in note 3). 
to grant certain heads of original jurisdiction to the Court in addition to those contained in Article III. ${ }^{42}$ The act also established the Court's appellate jurisdiction, which extended to the lower federal courts as well as the state courts. ${ }^{43}$ Despite the later salience of section 25's grant to the Court of the power to review state-court decisions, as demonstrated in such cases as Martin v Hunter's Lessee ${ }^{44}$ and Cohens v Virginia, ${ }^{45}$ in 1789 this provision generated less debate than did the architecture of inferior federal courts that the act set up. ${ }^{46}$

The structure of the lower federal courts consisted of two parts: thirteen district courts (one for each of the eleven then-ratifying states, plus Maine and Kentucky, which at that time were still part of Massachusetts and Virginia, respectively), each with its own district judge; and (2) three circuits, each requiring a quorum of two justices of the Supreme Court and the district judge of the particular district in which the court was sitting at a given time. The district courts possessed exclusive jurisdiction over admiralty cases and cases involving minor federal crimes, as well as concurrent jurisdiction with the circuit or state courts with respect to certain tort suits by aliens and certain suits by the United States. ${ }^{47}$ The circuit courts' original jurisdiction, meanwhile, extended to "all suits of a civil nature at common law or in equity, where the matter in dispute exceeds . . . the sum or value of five hundred dollars, and the United States are plaintiffs, or petitioners; or an alien is a party, or the suit is between a citizen of the State where the suit is brought, and a citizen of another State." ${ }^{48}$ While this jurisdiction was original, however, it was not exclusive but rather concurrent with the state courts. In addition, the circuit courts were given exclusive jurisdiction over all major federal crimes and appellate jurisdiction with respect to district-court cases. ${ }^{49}$ Thus, in the words of Julius Goebel, "[i]f the District Courts were viewed primarily as courts of special jurisdiction, the Circuit Courts were erected as courts of general original jurisdiction.”50

42 Judiciary Act of $1789 \S 13$. The provision regarding original jurisdiction was invalidated in Marbury $v$ Madison, 1 Cranch 137, 176-79 (1803).

43 Judiciary Act of $1789 \S \S 22,25$.

4414 Wheat 304 (1816) (civil cases).

4519 Wheat 264 (1821) (criminal cases).

464 DHSC at 30-31 (cited in note 32). The membership of the Senate committee represented this diversity of opinion, for Lee and Wingate had both been instructed by their respective state ratifying conventions to resist granting broad powers to the lower federal courts. See id; Goebel, Antecedents and Beginnings, 47071.

47 Judiciary Act of $1789 \S 9$.

48 Judiciary Act of $1789 \S 11$.

49 Id.

50 Goebel, Antecedents and Beginnings 475 (cited in note 41). 
As many modern commentators have noted, the 1789 act did not grant general federal question jurisdiction to the inferior federal courts. ${ }^{51}$ Indeed, Congress did not decisively embrace the modern, broadened version of federal question jurisdiction until 1875 . $^{52}$ To twentieth- and twenty-first-century eyes, this is a startling fact. ${ }^{53}$ Yet this sense of surprise results from the assumption that the Judiciary Act of 1789 belongs only to our own age rather than also to the late eighteenth century. After all, the language seems familiar: the act introduced district courts and circuit courts, diversity jurisdiction, amount-in-controversy requirements, and many other staples of a modern federal courts course. As the foregoing discussion illustrates, however, these were not "our" district courts or circuit courts. One need only consider the lack of a circuit-court bench, the relative autonomy of the district courts, and the absence of the type of firm appellate hierarchy that exists today to grasp how different the federal courts of 1789 were from those of today.

This pervasive sense of surprise is useful, however, because it demonstrates the importance of historicizing the judiciary act. To ask, "Why didn’t Congress grant general federal question jurisdiction until 1875?” is to get the analysis backward. A better, less teleological approach might be to ask, "Why did Congress grant federal question jurisdiction in 1875?” - or, indeed, “Did Congress attempt to grant federal question jurisdiction before 1875?" Such questions permit a more expansive view of the impetus behind the 1789 act, as well as a richer, more contextualized picture of constitutional thought in the early Republic, because they provide a means to connect the 1789 act with the 1801 act - which did, in fact, establish general federal question jurisdiction, albeit only temporarily. The 1801 act's modern identity as a federal-courts trivium could not seem more remote from the grave attention with which the 1789 act is greeted by scholars, law students, and constitutional commentators generally. But the Judiciary Act

51 See, for example, Maeva Marcus \& Natalie Wexler, The Judiciary Act of 1789: Political Compromise or Constitutional Interpretation?, in Marcus, ed, Origins of the Federal Judiciary 16 (cited in note 39) (stating that "no provision was made [in the 1789 act] for 'general federal question' jurisdiction in the lower federal courts”); Warren, New Light on the History of the Judiciary Act of 1789, 37 Harv L Rev at 131 (cited in note 3) (stating that "it was eighty-six years before legislation was enacted, in 1875, vesting the Federal Circuit Courts with jurisdiction in all cases arising under the Federal Constitution and laws”). But see Wilfred J. Ritz, Rewriting the History of the Judiciary Act of 1789: Exposing Myths, Challenging Premises, and Using New Evidence 59-60, 222 n.9 (Oklahoma: 1990) (Wythe Holt and L.H. LaRue, eds) (arguing that the act's "silence" does not amount to a denial of federal question jurisdiction, although the editors - who took over the manuscript after the author suffered a disabling stroke - take some exception to this claim).

52 See Act of Mar. 3, 1875, ch. 137, § 1, 18 Stat. 470 (providing circuit-court jurisdiction "of all suits of a civil nature at common law or in equity ... arising under the Constitution or laws of the United States, or treaties made, or which shall be made under their authority"). The modern grant of federal question, or "arising under," jurisdiction is now codified at 28 U.S.C. $§ 1331$ (providing that "[t]he district courts shall have original jurisdiction of all civil actions arising under the Constitution”).

53 See, for example, William R. Casto, The First Congress's Understanding of Its Authority Over the Federal Courts' Jurisdiction, 26 BC L Rev 1101, 1116 (1985) (“In retrospect, the most remarkable limitation upon the lower courts' jurisdiction was the absence of general federal question jurisdiction over civil cases.”). 
of 1801 - and, perhaps even more important, the vituperative political debate that preceded it in the 1790s - is important precisely because it reminds us of the essential foreignness of jurisdiction theory in the early Republic. Federal jurisdiction is an idea, and like all ideas it had a before and an after, a time when it did not exist and a later time when it did.

Even before President Washington signed the Judiciary Act of 1789 into law, supporters and critics alike had begun to wonder aloud whether a better system might be possible. Madison termed the act "pregnant with difficulties, not only as relating to a part of the constitution which has been most criticised, but being its own nature peculiarly complicated \& embarrassing." "54 (When the bill came before the House a few weeks later, however, Madison spoke in its favor; according to published reports, the delegate from Virginia argued that "[ $t$ ]he bill may not exactly suit any one member of the House, in all its parts - but it is as good as we can at present make it." ${ }^{\text {,55 }) ~ T h e ~ A n t i f e d e r a l i s t ~}$ Elbridge Gerry, representing Massachusetts in the First Congress, said of the judiciary, “[T]his department I dread as an awful tribunal," citing the federal courts' broad jurisdiction over common law, equity, and admiralty cases as well as the potential for abuse of power by judges who could not be removed by Congress. ${ }^{56}$

In keeping with the controversy that had surrounded the drafting of the act, within a year of its passage two reform plans were proposed. In December 1790, in response to a request from the House, Attorney General Edmund Randolph submitted a report containing recommendations for restructuring the federal judiciary. Randolph's report was followed just over two months later by a set of amendments to Article III drawn up by New York congressman Egbert Benson. Neither reform plan made much headway; on the contrary, both ended their days languishing in committee. ${ }^{57}$ Yet Randolph's plan attracted substantial press notice, suggesting that at least some portion of the public was interested in judicial reform. ${ }^{58}$ Both plans will be discussed at greater length below.

\section{Concurrence: Drawing Lines, Again.}

The intellectual transition from defining questions of political and legal authority in terms of sovereignty to defining them in terms of jurisdiction manifested itself most profoundly in the decade following the passage of the Judiciary Act of 1789. Writing in early September of that year, a few weeks prior to the passage of the act, Massachusetts congressman Fisher Ames sent a letter to his friend John Lowell (soon to become federal

\footnotetext{
54 Madison to Samuel Johnston, July 31, 1789, 4 DHSC at 491 (cited in note 32).

55 Gazette of the United States, Sept. 17, 1789, id. at 512.

${ }^{56}$ Gerry to John Wendell, Sept. 14, 1789, id. at 509.

574 DHSC at 168 (cited in note 32).

58 Id at 124.
} 
judge for the newly created district of Massachusetts) in which Ames detailed a speech that he had recently delivered on the House floor. Ames's remarks included the following passage:

What is jurisdiction? Authority to judge, derived from a superior power The law of the U. S. is the law of the land, but not the law of a state_ . . . Many tell me, the state judges must decide according to law, \& the offences \&c are defined by law. ... . If we ascend to the first principles of the Judicia[l] power, I think we shall find them analogous to my doctrine_.... 59

Ames clearly regarded jurisdiction as the fundamental currency of the federal republic and an ordered system of jurisdiction as the sine qua non of that republic's success. And what was jurisdiction, in Ames's view? “Authority to judge, derived from a superior power" - in other words, court-based authority, the source of which was a still higher level of power.

Ames's comments are, it must be said, somewhat elliptical. ${ }^{60}$ But they demonstrate the degree to which the concept of jurisdiction occupied the thoughts of politicians and theorists by 1789. The debates of the 1790s, which led to the passage of the Judiciary Act of 1801, centered on a pair of related themes. Both concerned the vertical distribution of authority between the states and the federal government - or, more broadly, between the component entities and the general government in a federal structure. The two themes were, first, the notion of concurrent jurisdiction, according to which bodies at multiple levels of government had the power to hear cases on a given topic or involving a given type of party; and second, the possibility of vesting the lowestlevel authorities with the power and duty to carry out the commands of higher-level authorities. In the 1790s, then, commentators explored the possibilities of embracing concurrent jurisdiction in state and federal courts as well as designating the state courts essentially as inferior federal courts.

In some sense, these were new issues. As subjects of the British Empire, Americans had devoted most of their political attention not to institutional arrangements within a largely agreed-upon system but rather to challenging the fundamental nature of the system itself. Thus, members of the colonial opposition had cobbled together an alternative vision that would come to be called "federalism" in their efforts to rebut the

\footnotetext{
59 Ames to Lowell, Sept. 3, 1789, 4 DHSC at 506 (cited in note 32). Ames had originally begun the second sentence “A power to judge” but replaced it with “Authority to judge.” Id.

60 Ames seems to have been aware that his remarks might not be understood. Writing to Lowell ten days later, Ames commented, “I endeavoured to explain the leading idea or principle of my Speech in Fenno’s paper [the Federalist Gazette of the United States]. . . not because I was under concern about it's [sic] reception with the people__ for on a legal question, I never supposed they would have either curiosity or understanding. But I was afraid that the lawyers $w^{\mathrm{d}}$ either hurry over or misconceive my doctrine, and deny it’s [sic] orthodoxy.” Ames to Lowell, Sept. 13, 1789, 4 DHSC at 507 (cited in note 32).
} 
hegemonic system of empire on which metropolitan authorities insisted. ${ }^{61}$ Early republicans, meanwhile, viewed their main task as settling on the mechanisms by which the new federal system would be maintained - a no less important or potentially acrimonious dispute, for the system was so new that its structure would in important respects determine its substance.

In another sense, however, the questions presented similar quandaries to those that had occupied the colonial opposition since the imperial struggles of the 1760s and 1770s. The crucial issue no longer concerned the nature of sovereignty in a compound political entity, but the new variable of jurisdiction - Ames's "authority to judge" - and its allocation among the United States' hard-won multiple sovereigns. Perhaps, then, it is not surprising that early republicans thought about these problems through some of the same intellectual lenses that had served them during the intra-imperial conflict. As we will see, when Americans in the 1790s considered how best to arrange their multilayered authorities, they often returned to familiar notions of imperium in imperio and linedrawing.

\section{A. $\quad$ Concurrent Jurisdiction; or, Parallel Judicial Tracks.}

The idea of concurrent jurisdiction was absolutely central to the early national efforts to theorize what federalism meant in practice. Yet various observers used the term in different senses that proceeded from distinct understandings of the appropriate baseline distribution of authority between the federal government and the states. At times, "concurrence" seems to have referred to very broad notions of how to manage multiple sovereigns operating within the same space; at other times, the term referred to a more finely grained vision of the institutional distribution of authority among various levels of courts and legislatures. Moreover, contemporaries disagreed regarding the direction of the sharing of power. Was concurrence in effect when an all-powerful general government allowed states to exercise some authority over federal issues, as Alexander Hamilton argued? Or was it the opposite situation, in which a state granted some of its plenary power to the general government, as Thomas Jefferson maintained? Although the meaning of concurrence remained contested throughout the early republican period, the term - and the basic concept of overlapping power - informed theorists on all sides of the debate.

In the broadest sense, the term "concurrence" referred in this context to a structure in which multiple levels of government within a single polity possess overlapping authority to regulate, legislate, or adjudicate. This was the sense in which Hamilton employed the label in Federalist No. 32. Addressing the Constitution's grant to Congress of the power to "lay and collect Taxes, Duties, Imposts and Excises," Hamilton reassured skeptics that the states would nonetheless retain the "independent and uncontrolable [sic] authority to raise their own revenues for the supply of their own wants" - a power that had been central to the colonies' claims of independence since the 1760s. ${ }^{62}$ Because the

${ }^{61}$ See LaCroix, A Well-Constructed Union at 18-89 (cited in note 12).

62 US Const Art I, § 8, cl 1; Federalist 32 (Hamilton), in The Federalist 199 (cited in note 13). 
Constitution "aims only at a partial Union or consolidation," Hamilton reasoned, the states necessarily retained "all of the rights of sovereignty which they before had" and which were not by the Constitution "exclusively delegated to the United States."63 The consequence of such an arrangement would, Hamilton concluded, mean that in certain areas - such as taxation of "all articles other than exports and imports" - citizens might be subject to "a concurrent and coequal authority in the United States and in the individual States." 64 In other words, not all powers associated with the federal government were vested exclusively in the federal government.

Since the 1760s, the taxation issue had implicated questions about overlapping, or concurrent, legislative powers. By 1789, however, the debate had shifted to include concurrent judicial power. Here, too, Publius had something to say. In Federalist No. 82, Hamilton took up the question of the relationship between the state courts and the federal courts. (Note that at the time that Hamilton was writing, the federal courts comprised only the Supreme Court; however, Hamilton's references to "the national tribunals" suggests that he, like many of his contemporaries, assumed that the First Congress would indeed establish inferior federal courts. ${ }^{65}$ ) Here again, Hamilton was sanguine about the prospects for concurrent jurisdiction. Reading Article III, section 1 as a nonexclusive description of the "organs" through which the federal judicial power was to be exercised, Hamilton argued that the states retained jurisdiction "of causes of which the state courts have previous cognizance."66 This concurrence did not extend, however, to "cases which may grow out of, and be peculiar to the constitution to be established.",67 The guiding principle for Hamilton, then, was that the state courts might permissibly hear cases "arising under the laws of the union," as long as the Constitution or an act of Congress did not expressly commit that class of case to the federal courts. ${ }^{68}$

Hamilton’s justifications for this concurrent judicial power are interesting because they represent a subtle but important shift from some Americans’ pre-Revolutionary vision of the proper allocation of authority in a federal government. Beginning in the 1760s, colonists had objected to increased taxation and regulation by Parliament based on their belief that such measures violated what they regarded as the essential structure of the imperial union. That structure, the colonists argued, did not depend on the territorybased view of authority on which metropolitan officials insisted, and which maintained that the colonies were integrated into the British dominions and therefore subject to the full range of regulation by Parliament. Rather, Anglo-Americans argued for a subject-

63 Id at 200.

64 Id at 201.

65 Federalist 82 (Hamilton), in The Federalist 553 (cited in note 13).

66 US Const Art III, § 1, cl 1; Federalist 82, in The Federalist 554 (cited in note 13).

67 Id.

68 Id at 555. 
matter conception of political and legal power that allocated jurisdiction among multiple governmental actors (in their case, between Parliament and the colonies' own assemblies), depending on the particular thing or activity to be regulated. ${ }^{69}$

In the colonists' view, this subject-matter approach to authority meant that certain types of issues were the exclusive province of colonial governments and were therefore beyond the power of Parliament (and, in some cases, the Crown) to regulate. Provincial spokespeople denominated these areas of exclusively local regulation variously as “internal” (as opposed to "external”), “special,” or “domestic,” or as related to locally raised "revenue" that they believed ought to be reinvested locally rather than disbursed into the general accounts of the realm. During the Stamp Act crisis and the ensuing, decade-long cycle of parliamentary legislation and colonial outrage, commentators such as Richard Bland of Virginia put the matter increasingly bluntly. For purposes of external government, Bland acknowledged, “we are and must be subject to the authority of the British Parliament." With respect to internal government, however, Bland contended that "any tax respecting our INTERNAL polity which may hereafter be imposed on us by act of Parliament is arbitrary, as depriving us of our rights, and may be opposed.” On this basis, Bland argued, “[T]he legislature of the colony have a right to enact ANY law they shall think necessary for their INTERNAL government."70 By 1773, members of the Massachusetts assembly were invoking Continental theorists such as Samuel von Pufendorf to support their demands to be treated as coequal entities in a system of states, with a concomitant degree of legislative autonomy within its defined sphere. $^{71}$ On the eve of the Revolution, then, American commentators increasingly advocated a governmental architecture that comprised multiple sources of lawmaking authority operating largely in parallel, with each responsible for a specific category of subjects. As a report of the upper house of the Massachusetts assembly described the relationship between that body and Parliament in 1773, "[T]he two Powers are not incompatible, and do subsist together, each restraining its Acts to their Constitutional Objects.",72

As these comments demonstrate, much prewar Anglo-American thinking about the nature of authority within a compound government centered on what contemporaries viewed as the absolute necessity of setting boundaries between the respective levels of government. Delineation was the order of the day, and a transatlantic obsession with drawing lines - and, indeed, with the rhetoric of line-drawing - took hold. The royal governor of Massachusetts, Thomas Hutchinson, declared in 1773, "I know of no Line

${ }^{69}$ See LaCroix, A Well-Constructed Union at 79 (cited in note 12).

${ }^{70}$ Common Sense [Richard Bland], The Colonel Dismounted: or the Rector Vindicated. In a Letter addressed to His Reverence: Containing a Dissertation upon the Constitution of the Colony 22-23 (Williamsburg: Joseph Royle 1764).

${ }^{71}$ See LaCroix, A Well-Constructed Union 119-20 (cited in note 12).

72 Alden Bradford, ed, Speeches of the Governors of Massachusetts, From 1765 to 1775 at 86-87 (Boston: Russell and Gardner 1818). See also LaCroix, A Well-Constructed Union 90-165 (cited in note 12). 
that can be drawn between the supreme Authority of Parliament and the total Independence of the Colonies: it is impossible there should be two independent Legislatures in one and the same State ....”73 A pseudonymous writer in the BostonGazette and Country Journal took a different view, stating, "NO Line can be drawn between the usurped Power of Parliament, and a State of Slavery in the Colonies."74 Advocates of metropolitan supremacy tended to argue for what might be considered a measure of concurrence, insofar as they were willing to permit colonial assemblies to act as subordinate and dependent municipal bodies. Members of the colonial opposition, by contrast, rejected concurrence because they viewed it as a tool of continued metropolitan dominance. The only workable scenario by which the colonies could remain in the empire, they believed, was for provincial and central legislatures to operate along distinct and nonintersecting lines.

By embracing concurrent powers as a natural consequence of the Constitution's structure, Hamilton implied that this strict demarcation along subject-matter lines might not be relevant to the new republic. Indeed, his formulation of the jurisdiction question referred not at all to the separation of authority that had obtained within the British Empire. Rather, his description of those powers suggested a certain degree of ambiguity, at least with respect to concurrent state- and federal-court jurisdiction. State courts might permissibly take cognizance of cases arising under federal law, Hamilton stated, as long as the state had jurisdiction over the persons of the parties. "The judiciary power of every government looks beyond its own local or municipal laws, and in civil cases lays hold of all subjects of litigation between parties within its jurisdiction though the causes of dispute are relative to the laws of the most distant part of that globe," he wrote in Federalist No. 82. "Those of Japan not less than of New-York may furnish the objects of legal discussion to our courts."

According to this line of analysis, subject matter was irrelevant; the only pertinent consideration for a court was whether the parties were physically within its jurisdiction. Such a regime would necessarily lead to overlaps and would therefore run afoul of the parallelism principle articulated by prewar colonial commentators. ${ }^{76}$ Yet Hamilton took a slightly different approach when he argued that the Supreme Court would necessarily possess appellate jurisdiction over state-court cases involving federal law. "The objects of appeal, not the tribunals from which it is to be made, are alone contemplated" when

${ }^{73}$ Id at 109.

74 “An Elector,” Boston-Gazette and Country Journal (Jan. 11, 1773).

${ }^{75}$ Federalist 82 (Hamilton), in The Federalist 555 (cited in note 13).

${ }^{76}$ See, for example, John Dickinson's prewar argument against concurrent authority in Parliament and the colonial assemblies over revenue matters. "The single question is whether the parliament can legally impose duties to be paid by the people of these colonies only FOR THE SOLE PURPOSE OF RAISING A REVENUE, on commodities which she obliges us to take from her alone; or, in other words, whether the parliament can legally take money out of our pockets without our consent." [John Dickinson], Letters from a Farmer in Pennsylvania, to the Inhabitants of the British Colonies 26 (Boston: Mein and Fleeming, 1768). 
determining whether a case was eligible for appeal to the Supreme Court, Hamilton wrote. Here, then, the relevant criterion was that the case arose under the law of the United States, not the largely happenstance fact of the geographic location in which it originated. Subject-matter questions were thus largely irrelevant to Hamilton for purposes of expanding state-court jurisdiction to include federal causes of action, but they were dispositive in determining the scope of the Supreme Court's jurisdiction.

The interest in exploring at least the possibility of concurrence as a basis for the federal republic therefore set the constitutional debates of the ratification and early republican periods apart from those of the 1760s and 1770s. Whereas many colonists had resisted concurrence and pressed for subject-matter-specific boundaries between local and metropolitan authorities, Hamilton and other commentators in 1787 treated overlapping boundaries between states and federal government as a potential means of granting a measure of power to the states. This may seem counterintuitive; after all, the colonists viewed concurrence not as an opportunity to stake their claim to a piece of the larger government but as a transfer of power back to Westminster. How, then, could Hamilton present concurrence as an acknowledgment of the states' "primitive jurisdiction"? ${ }^{77}$ Consider again his statement in Federalist No. 32: "the plan of the Convention aims only at a partial Union or consolidation," and therefore "the State Governments would clearly retain all the rights of sovereignty which they before had and which were not by that act exclusively delegated to the United States."78 In a world such as that of the 1760s and 1770s, where the central controversy concerned not membership and control of a central government but independence from that government, concurrence provided a means for the center to overreach itself and exert power over the provinces. But perhaps in a world such as that of 1787, where complete union or consolidation appeared to be a possibility, retaining concurrent jurisdiction might reasonably be construed as a victory for the states. ${ }^{79}$

Still, one important difference between the colonial and early republican discussions of concurrence was the institutional focus of each. Whereas the colonists devoted themselves to analyzing competing legislative claims to power (the provincial assemblies versus Parliament), commentators in the ratification period and afterward increasingly emphasized the judicial side of concurrence. Hamilton's analysis in The Federalist contemplated both species of concurrence. Increasingly after 1789, however, the drive to establish the inferior federal courts shifted the emphasis of structural

\footnotetext{
77 Federalist 82 (Hamilton), in The Federalist 555 (cited in note 13).

${ }^{78}$ Federalist 32 (Hamilton), in id 200.

79 St. George Tucker, however, took the view that concurrent powers of legislation were not a benison to state authority but rather a means of chipping away at the power of the states. Describing the "some few instances" - such as bankruptcy - in which "the grand boundary between the limits of federal and state jurisdiction ... has not been strictly adhered to in the federal constitution,” Tucker observed that such encroachments were "in derogation of the municipal jurisdiction of the several states" and therefore should be "strictly construed." St. George Tucker, View of the Constitution of the United States With Selected Writings 127 (Liberty Fund 1999).
} 
discussions away from issues of legislative competition, with their colonial resonance, and toward the new problem of organizing multiple judiciaries within a single overarching polity. The advent of the lower federal courts added a new urgency to this inquiry. Thus, by 1803, Virginia jurist St. George Tucker could observe that the "grand boundary" that "mark[ed] the obvious limits between the federal and state jurisdictions" coexisted with "some few cases, where, by a special provision contained in the constitution either concurrent, or exclusive, jurisdiction is granted to the federal government." ${ }^{\text {„0 }}$ Notably, in contrast to Hamilton's view, Tucker's vision of concurrence amounted to a special invitation to the federal courts, not the state courts, to take jurisdiction over a select group of cases. The two theorists thus differed in their default assumptions as to which level of courts was the norm and which the exception, but they both presented some degree of judicial concurrency as necessary to the larger federal system.

But the fact that concurrence was a frequent topic of discussion in the ratification period does not mean that contemporaries had uniformly warm regard for it. Some observers opposed any form of concurrence, believing that any overlap between the state and federal judiciaries would only lead to confusion and either centralization or disintegration, depending on the observer's particular array of anxieties about federalism. Virginia judge Joseph Jones wrote to Madison in July 1789 to note his discomfort with the draft judiciary bill, which he believed muddied rather than clarified the relationships among the various courts. "[T] he different powers and jurisdictions of the Courts would have been more clearly seen had they been taken up in several bills, each describing the province and boundary of the Court to which it particularly applied," he observed. But his objections extended beyond the form of the bill. To Jones, even the act's few references to the state courts (i.e., section 9's language regarding concurrent jurisdiction to state courts for cases involving tort claims by aliens in violation of the law of nations or a treaty and section 25's provision regarding appeals to the Supreme Court) obscured the true scope of the federal courts' reach. "[W]here there is danger of clashing jurisdictions, the limits should be defined as acurately [sic] as may be, and this danger will exist where there are concurrent jurisdictions," Jones contended. ${ }^{81}$ Congressman John Brown, who represented the Kentucky district of Virginia, sounded a similar note of caution, describing his fear that "great difficulties will arise from the concurrent Jurisdiction of the Federal with the State Court, which will unavoidably occasion great embarrassment \& clashing." Brown followed this statement with a guarded endorsement of the act, however, calling it "as good I believe as we at present could make it.",82

Edmund Randolph's 1790 plan to amend the 1789 act, meanwhile, offered reforms while also attempting to correct some of the act's ambiguities concerning concurrence. As has been noted, the attorney general's proposals failed to gain sufficient

\footnotetext{
${ }^{80}$ Id at 128.

${ }^{81}$ Jones to Madison, July 3, 1789, 4 DHSC 441-42 (cited in note 32).

${ }^{82}$ Brown to Harry Innes, Sept. 28, 1789, id at 519-20.
} 
support to be adopted. Nevertheless, they demonstrate the ways in which observers were working to reconceptualize and reconfigure jurisdiction in the years following the passage of the 1789 act. Randolph's scheme offered several significant changes to the structure erected by the act. First, the plan whittled away the states' jurisdiction over nominally federal matters to such a degree that concurrent authority was rendered virtually nonexistent. As Maeva Marcus notes, Randolph’s “central premise” was that "federal and state jurisdictions should be completely separate." ${ }^{\text {"83 }}$ From this premise followed a much more sweeping grant of authority to the district and circuit courts as well as language that explicitly stripped the state courts of the power to take cognizance of several of the most common federal causes of action.

The plan's broad grant to the inferior federal courts included original jurisdiction "of all cases in law and equity, arising ... [under] the Constitution of the United States . . . [t]he laws of the United States . . . and [t]reaties made, or which shall be made under their authority." "84 In other words, Randolph sought to vest the lower federal courts with the full range of original jurisdiction under Article III - that is, general federal question jurisdiction. ${ }^{85}$ State courts, meanwhile, were expressly prohibited from hearing a number types of of cases, including admiralty and maritime cases, cases in which the United States or a particular state was a defendant (except in cases of consent by the state), cases involving land grants by different states, treason cases, federal criminal cases (absent a specific congressional provision establishing state courts' jurisdiction), and cases involving congressionally created rights with federal remedies. ${ }^{86}$ Moreover, an apparent narrowing of the Supreme Court's power to review state-court decisions accompanied this expansion of the lower federal courts' jurisdiction, although the precise contours of the restriction are not entirely clear. ${ }^{87}$

Randolph's proposals appear to have confounded his contemporaries. Alfred Moore, a future justice of the Supreme Court, remarked to North Carolina senator Samuel

834 DHSC at 122-23 (cited in note 32).

${ }^{84}$ Report of the Attorney-General to the House of Representatives, id at 140.

${ }^{85}$ See 4 DHSC at 123 (cited in note 32).

${ }^{86}$ Report of the Attorney-General to the House of Representatives, id at 140.

${ }^{87}$ Randolph's attitude toward the Supreme Court's appellate review of state-court decisions appears somewhat ambivalent. On one hand, in the preface to the report Randolph refers to "convert[ing] the supreme court of the United States into an appellate tribunal over the supreme courts of the several states," suggesting that such a relationship would be novel; moreover, in discussing the phrase "appellate jurisdiction," Randolph contends that "this phrase must be pressed close to the matter of the third article of the Constitution, which is the judicial power of the United States, without blending state courts." Id at 132. Both these observations are offered as the arguments of those who object to the granting the Court appellate power over state-court decisions, but Randolph at times appears to adopt these arguments as his own. The report itself did provide for the issuance of writs of certiorari from the Supreme Court to the circuit and state courts. See id at 153. Marcus reads the report as prohibiting the Court from hearing appeals from the state courts, however, and as substituting a broadened power for parties to remove cases from state to federal court. See 4 DHSC at 124 \& n.14 (cited in note 32). 
Johnston that "there appears an utter confusion in $\mathrm{M}^{\mathrm{r}}$ Attorney's Ideas," noting in particular the apparent conflict between Randolph's claim that "the State Courts ought to be excluded because not under the Control of the federal Courts" and his claim that the state courts' proceedings “are in some instances subject to the federal Judiciary, because that Judiciary must ex natura rei control determinations that counteract the operation of the Constitution." 88

Despite these apparent ambiguities, Randolph's plan is important because it demonstrates the degree to which the scope and nature of federal jurisdiction remained a contested issue in the 1790s. Furthermore, the proposal clearly shows Randolph endorsing an expanded vision of "arising under" jurisdiction at the same time that he was struggling to articulate clearer boundaries between federal and state courts than those set forth in the 1789 act. $^{89}$ In this way, Randolph's plan eschewed the relatively welcoming attitude toward concurrent jurisdiction that Hamilton had adopted in his Federalist essays, moving instead toward a notion of the judicial power of the United States as something extraordinary and perhaps beyond the ken of state courts.

Of course, Randolph's plan did not mandate that cases arising under the laws of the United States fell exclusively within the jurisdiction of the federal courts; the report merely stated that the lower federal courts possessed original jurisdiction over such cases. This capacious view of the federal judicial power, however, hearkened to the subjectmatter-driven analyses of the 1760s and 1770s, insofar as it looked not to the nature of the parties or the jurisdiction in which their case arose but rather to the character of the claim at issue. Randolph's conception thus also represented a shift away from the 1789 act's focus on the parties' identity or location, and toward the underlying subject of the cause of action as decisive of jurisdiction. ${ }^{90}$ In other words, the jurisdictional lines drawn by the attorney general resembled the prewar notion of sovereignty as attaching to specific subjects of regulation.

\footnotetext{
${ }^{88}$ Moore to Johnston, Fed. 23, 1791, id at 555-56 (translating the Latin phrase as "by the nature of the thing”).

${ }^{89}$ Writing in 1794, James Kent articulated a similarly broad vision of federal jurisdiction, although his reasoning different somewhat from Randolph's. Kent compared the judicial power with the legislative power and concluded that the scope of federal courts' authority necessarily had to at least match that of Congress. "This power in the Judicial, of determining the constitutionality of Laws, is necessary to preserve the equilibrium of the government, and prevent usurpations of one part upon another," Kent wrote, adding that "of all the parts of government, the Legislative body is by far the most impetuous and powerful." The judicial power, however, being "the weakest of all . . . ought not in sound theory to be left naked without any constitutional means of defence." Thus, he concluded, the judiciary and the legislature should be regarded as "co-ordinate powers." James Kent, An Introductory Lecture to a Course of Law Lectures in 2 American Political Writing During the Founding Era, 1760-1805 at 943 (Liberty Press 1983) (Charles S. Hyneman and Donald S. Lutz, eds.).

${ }^{90}$ Consider on this point Casto, The First Congress's Understanding of Its Authority Over the Federal Courts' Jurisdiction, 26 BC L Rev at 1116 (cited in note 53) (noting, in the context of general federal question jurisdiction, that under the 1789 act, "the circuit courts were vested with jurisdiction keyed to the nature of the parties rather than the nature of the dispute").
} 


\section{B. States Courts as Federal Courts; or, Deputizing the States.}

In addition to contemplating concurrent arrangements, in which the judicial powers of the federal and state governments overlapped, some theorists in the 1790s considered whether the state courts could themselves be integrated into the emerging judicial structure. In this scenario, the state courts would in effect function as inferior federal courts. The idea had circulated since the Philadelphia and ratifying conventions; after all, the language of the Supremacy Clause singled out "the Judges in every State" to be bound by "the supreme Law of the Land." ${ }^{91}$ Because the state courts were thus already obliged to follow and enforce the laws of the United States, the argument ran, inferior federal courts were not necessary to the constitutional structure; on the contrary, Congress could permissibly refrain from establishing such courts altogether. ${ }^{92}$

Such an argument appealed especially to Antifederalists who worried that the creation of inferior federal courts amounted to the thin edge of the nationalizing wedge, intruding and encroaching on the reserved powers of the states. Indeed, outspoken critics of broad national power such as Luther Martin had initially supported the Supremacy Clause precisely because they believed that its reliance on state courts threatened less intrusion on state prerogatives than did the federal negative. " "[W]hat is there left to the State Courts?,” George Mason inquired of his colleagues in the Virginia ratifying convention as they debated Article I's grant to Congress of the power to establish inferior federal courts. "When we consider the nature of these Courts, we must conclude, that their effect and operation will be utterly to destroy the State Governments. ... The discrimination between their Judicial power and that of the States, exists therefore but in name." ${ }^{94}$ For Mason and others who advocated a general government with circumscribed powers, the prospect of swelling ranks of federal courts - with concomitant growth in claims of federal jurisdiction - threatened nothing less than "the annihilation of the state judiciaries." ${ }^{95}$

${ }^{91}$ US Const Art VI, cl 2. For a recent discussion of the propriety of state courts' acting as inferior tribunals, see James E. Pfander, Federal Supremacy, State Court Inferiority, and the Constitutionality of Jurisdiction-Stripping Legislation, 101 Nw U L Rev 191 (2007).

${ }^{92}$ On the related question whether Article III requires Congress to establish some inferior federal courts, see the sources cited in note 14

93 See generally Charles F. Hobson, The Negative on State Laws: James Madison, the Constitution, and the Crisis of Republican Government, 36 Wm \& Mary Q 215, 228 (3d ser., 1979). The final version of the Supremacy Clause failed to win Martin's support, however. In a related vein, “Federal Farmer” opposed the 1789 act's establishment of federal diversity jurisdiction, arguing that such jurisdiction was unnecessary, as such suits could also be brought in state court with appeal to the Supreme Court. Letters from the Federal Farmer, 1 The Debate on the Constitution 271 (cited in note 31).

${ }^{94} 2$ id at 720.

${ }^{95}$ Centinel Revived, No. 26, Independent Gazetteer (Philadelphia), Aug. 29, 1789. 
In the 1790s, following ratification, some commentators continued to make the case for relying on state courts to conduct the first level of federal judicial business. "[T] he whole judicial system is a giddy profusion, and quite unnecessary," lamented the pseudonymous “Rusticus” in Boston’s Independent Chronicle.

The business might have been done in the State Courts, with a balance or check, raised by giving a Court of the Union, power to examine and correct those cases where foreigners or persons of different States are concerned. And all this unweildy [sic] and useless machinery of Circuit, District and Supreme Courts might have been omitted. $^{96}$

Such criticisms briefly gained momentum in March 1791, when New York congressman Egbert Benson introduced a set of amendments to Article III that echoed Rusticus's sentiments. The centerpiece of Benson's plan was a provision requiring Congress to establish in each state a "General Judicial Court," either by denominating the highest existing state court as such or by creating a new court. The general judicial court, which was to be "regulated as the Congress shall prescribe," would have original jurisdiction "in all cases to which the judicial power of the United States doth extend," as well as appellate jurisdiction over cases from other courts within the state. ${ }^{97}$ Moreover, although the judges of this new court would receive their salaries from the federal government and be subject to the good behavior standard, they could be impeached by either the House of Representatives or the state legislature. Judges from state courts that were declared general judicial courts by Congress would become judges of the new courts "by force of their appointments" as state-court judges, and the powers and duties of the state court would "devolve on the judges of the general judicial court." concluded with an explicit statement of the new courts' dual nature: state judicial officers would be "held to execute their respective offices for carrying into effect the laws of the United States" as well as in addition to the duties assigned to them by the laws of the state."99 Benson's amendments thus shunted aside fine distinctions relating to concurrence between state and federal courts and instead essentially deputized the state courts to serve Congress and the federal judicial power.

Although the Benson proposal received widespread attention in the press, it too was dispatched to committee and never heard from again. ${ }^{100}$ Despite this ignominious fate, Benson's amendments highlight a tension in the arguments for increased reliance on

\footnotetext{
96 “Rusticus,” Independent Chronicle (Boston), Aug. 26, 1790.

974 DHSC at 170 (cited in note 32).

98 Id at $170-71$.

99 Id at 172.

100 Id at 168 n.4. Marcus states that the amendments were likely intended "less as a topic for debate than as a political statement” by the Hamiltonian Benson. Id at 168.
} 
state courts. The arguments of anti-consolidationists such as Martin and Mason could easily slide into plans such as Benson's; putative goals of state autonomy might quickly give way to schemes to subordinate the states into mere departments, administrative subdivisions of the general government. State courts might be able to hear diversity cases, cases involving congressional statutes, treaties, and other federal causes in the first instance, but would not such an arrangement amount to the state courts' becoming coopted by the general government rather than maintaining their prized autonomy? Some commentators, such as one writing under the nom de plume "Curtius," expressed suspicion along these lines in considering the Benson amendments and similar plans:

[O]n taking a candid and impartial survey of the amendments in question, it is obvious that the sole scope and intention of them is to absorbe [sic] and annihilate those very governments, to which the general one owes its existence; or at best, to convert them into extensive but feeble CORPORATIONS. ${ }^{101}$

Throughout the 1780s and 1790s, observers with a wide array of agendas and commitments argued that the state courts ought to have an institutional place in the new federal edifice. Some hoped that the state courts, as already-extant and functioning adjudicatory bodies, could be folded directly into the federal apparatus. Others wanted robust state judiciaries to act as buffers against what they viewed as the creeping expansion of federal question jurisdiction (and, with it, the homogenizing, centralizing force of union). Opponents of a broader brief for the state courts, however, offered a wide array of arguments against further incorporating them into the federal structure. While some of these critics hoped that the state courts might for their own protection be cordoned off from the federal judiciary, others argued that the state courts must be kept out because they were untrustworthy and might corrupt the federal system.

Taking the former, protective view of state courts, Pennsylvania congressman William Maclay suggested that the states were already implicated in the federal structure, whether they liked it or (as in his case) not. Just as the Constitution had "meant to swallow up all the state Constitutions by degrees," he insisted, the 1789 act aimed to "Swallow by degrees all the State Judiciaries." 102 Despite his role as a member of the committee that had drafted the 1789 act, Maclay ultimately could not bring himself to vote for the act, which he called "a Vile law System, calculated for Expence, and with a design to draw by degrees all law business into the federal Courts."103

Federalist Fisher Ames of Massachusetts had different concerns, however. Ames contended that the state courts possessed the power to range freely over the full landscape of both federal and state matters. But how, if at all, Ames wondered, could the state

\footnotetext{
101 “Curtius,” Augusta (Ga.) Chronicle, May 28, 1791, in 4 DHSC at 559 (cited in note 32).

102 Id at 473 .

${ }^{103}$ Id.
} 
courts ever be checked? Vesting state courts with any significant jurisdiction over federal questions risked profound problems of representation, insofar as it lodged decisionmaking power in officials whose allegiance was only to their local community, not the interests of the Union as a whole. "Will the state judges act quasi state judges or as federal[?]" Ames inquired. "If as state judges, how can you add duties not required by the states who commissioned them and how can you compel them to perform such duties, or punish for the violation or neglect." ${ }^{104}$ Furthermore, Ames wondered, would one even be able to determine in what capacity a state judge was acting in any given moment? "The jurisdictions being concurrent, how will you distinguish when they act as state, and when as federal judges _ sometimes a nice question this."105

The map created by the 1789 act expressed this prevailing uncertainty as to how the state courts ought to be treated. The act's structure not only accepted the states as preexisting polities but actually overlaid the new federal districts onto the existing map of the states - even borrowing the states' names. Thus, the districts described in the act comprised "one to consist of the State of Connecticut, and to be called Connecticut District; one to consist of the State of New York, and to be called New York District," and so forth through the other nine states and two subsets of states (Maine and Kentucky). ${ }^{106}$ This overlap between the state and federal maps appears not to have raised significant objections during the debates on the act. Notably, an amendment to breach state boundaries by creating a multi-state district covering portions of Maryland, Virginia, and Delaware failed in the House, suggesting that maintaining the states' territorial integrity - rather than drawing entirely new political boundaries solely for federal purposes - was important to members. ${ }^{107}$

Was this political and legal congruence evidence of the federal government's desire to press the states into its service, or was it an acknowledgment of the states' importance, perhaps even a sign of respect? Many contemporaries regarded the layout of the districts, and their number, as an attempt to ensure that the judicial power of the United States could be felt throughout the nation while also establishing it as superior to the judiciary of any one state. ${ }^{108}$ During the 1790s, however, many observers complained that the seats of federal government within any given state were too remote. One commentator suggested that the upshot of this arrangement - which created, in the words

104 Ames to John Lowell, July 28, 1789, id at 481.

105 Id.

106 Judiciary Act of $1789 \S 2$.

1074 DHSC at 39 (cited in note 32).

108 See, for example, “A Citizen,” Washington Federalist, Jan. 26, 1801 (noting that "[t]he difficulty of organizing the Judiciary of the U. States, so as, agreeably to the Constitution to vest in the General Government a judicial authority over individual States; and, at the same time to establish a commodious administration of justice, was early foreseen”). See also Federalist 81 (Hamilton) in The Federalist 546-57 (arguing for the establishment of "four or five, or half a dozen districts" instead of relying on state courts to serve as inferior courts) (cited in note 13). 
of Julius Goebel, “a species of artificial federal entity”- was confusion leavened with a lack of popular identification with the federal government. 109 "The laws of the United States, coming into discussion only in one court in each state, are but little known, and, at a distance from that court they are considered as foreign laws," lamented "A Citizen" in the Washington Federalist. "The contrast between the state and the federal administration of justice appears strong, and the advantage manifest against the federal judiciary."110 Thus, despite efforts by Randolph and others to keep separate the multiple levels of judicial power, the complexities of concurrence - both of subject matter and of territorial space - were very much on commentators' minds throughout the 1790s.

Here was another respect in which the debates of the post-ratification period echoed the arguments of the 1760s and 1770s: commentators in the early Republic employed a similar vocabulary of line-drawing and imperium in imperio to that of their predecessors a few decades earlier. Even as they experimented with concurrence and considered deputizing state courts to act as inferior federal courts, early republican theorists continued to think about governmental structure in terms of the boundaries between different sovereigns and different sources of authority. The drive to delineate governmental spheres had preoccupied Thomas Hutchinson and the members of Boston's colonial opposition in 1773, and it continued to needle Americans in the post-ratification period.

The urgency was even more profound in the later years, as "the judicial" (as Ames and others termed it) increasingly became the institutional site for hashing out the competing versions of federalism that had emerged since the 1760s. ${ }^{111}$ In this anxious context, the old tropes of sovereignty gained new force and meaning. During the 1789 debates, William Paterson conjured up the imperium in imperio specter: "We are a Combination of Republics _ a number of free States confederated together, \& forming a social League." Within this league, Paterson went on, the Union and each of the several states possessed "a Head _ each operating upon different Objects." 112 Given such an arrangement, could the state courts reach outside the state realm to take cognizance of federal causes of action? No, Paterson answered. Granting federal authority to judges "chosen by the respective States; in whose Election the Union has no Voice, and over whom they have little or no Control" was nothing less than "a Solecism in Politicks - a Novelty in Gov." "113 By 1791, Massachusetts Federalist Theodore Sedgwick was bemoaning the problems that "arise from an administration of justice by two distinct \& independent sovereignties over the same persons, in the same place and at the same

\footnotetext{
109 Goebel, Antecedents and Beginnings at 471 (cited in note 41).

110 “A Citizen,” Washington Federalist, Jan. 26, 1801.

111 See, for example, Ames to Lowell, July 28, 1789, 4 DHSC at 481 (cited in note 32).

112 Id at 414.

113 Id at 415 .
} 
time.”114 Sedgwick made his observations just a few weeks before Justice James Wilson wrote to Washington with a proposal for a digest of federal law, observing that "the difficult and delicate Line of Authority ... must be run."115 Born in the provincial legislatures of a mercantile, transatlantic empire, the vocabulary of federalism found new salience among the multiple judiciaries of the early Republic.

The ongoing constitutional debates of the 1790s demonstrated the fragile nature of the definitions of political and legal authority that many Americans believed they had worked out in the course of the conflict with Britain. Now, conscious of their inheritance as the second generation since the founding, early republican observers turned anxiously back to old themes of imperium in imperio, multiple sovereigns, and line-drawing. ${ }^{116}$ At the same time, however, they became fascinated with ideas of concurrence - of multiple and overlapping powers, especially judicial powers. ${ }^{117}$ These warring impulses gained intensity throughout the 1790s until, fueled by partisan rancor that few in the first generation had anticipated, they exploded in the tumults of 1800 and 1801.

III. $\quad$ From federal to Federal Judicial Power: The Judiciary Act of 1801.

As the preceding discussion has suggested, beginning in 1789, judicial power emerged as the focus of both practical and theoretical disputes about the nature of multilayered authority. The judiciary became the key site of federalism during this period, with jurisdiction as the tool by which theorists and politicians carved up the levels of power among governments and people.

That was the scene in 1789 and for much of the subsequent decade. Around 1800, however, that picture changed. From the domain of federalism in the 1780 s and 1790 s, judicial power became the redoubt of Federalism in the 1800s. The story of the presidential election (or "revolution," as Jefferson termed it ${ }^{118}$ ) of 1800 is well known, as is the subsequent rise of the Jeffersonian-Republican party and the eclipse of the

114 Sedgwick to Peter Van Schaack, Nov. 20, 1791, id at 566.

115 Wilson to Washington, Dec. 31, 1791, id at 572.

116 On the burdens that second- and later-generation Americans perceived themselves as bearing, see, for example, Joyce Appleby, Inheriting the Revolution: The First Generation of Americans (Harvard 2000) (discussing Americans born between 1776 and 1830); Perry Miller, Errand Into the Wilderness (Harvard 1956) (describing the spiritual crisis of second-generation Puritans in New England); Henry Adams, The Education of Henry Adams: An Autobiography (Houghton Mifflin 1935) (describing and illustrating later generations' sense of anxiety and fears of declension).

117 On discussions of concurrence in the ratification debates, see Hulsebosch, Constituting Empire 223, 241-42, 382-83 nn. (cited in note 10).

118 Jefferson to John Dickinson, Mar. 6, 1801, in 33 The Papers of Thomas Jefferson 196-97 (Princeton 2007) (Barbara Oberg, ed). 
Federalists. ${ }^{119}$ A familiar part of this tale is the flight of the Federalists to the judiciary in the wake of the schism that resulted in the first party system and the "loss" of the presidency and Congress to the Jeffersonians. ${ }^{120}$

This story, however, often treats the Judiciary Act of 1801 as an artifact of the election of 1800, a manifestation of partisan rancor with little to tell us about constitutional thought. Hence the emphasis, as suggested in the quotation from Kathryn Turner Preyer above, on the judiciary act's passage in 1801 as a mere prelude to its repeal in $1802 .{ }^{121}$ But there is more to the 1801 act than this narrative of Federalist overreaching and Republican chastisement suggests. Like the 1789 act, the 1801 act should be viewed not simply from the modern perspective of the forward march of the federal courts to the twenty-first century, but rather from the early republican angle of making divided government work. To be sure, party politics are central to this account; as Joanne Freeman points out, a "crisis mentality" had seized the American political scene by 1800, stemming in large part by the hardening of party lines in a time when "normalcy" was understood as "the absence of organized national parties, not a wellfunctioning national party system."122 But more was at issue in the 1801 act than the partitioning of the federal empire between Federalist and Republican claimants to rule. Ideas were at stake in the debates surrounding the 1801 act, just as they had been in 1789 .

The turn-of-the-century constitutional struggle was not merely a cover for partisan conflict; to interpret the period in that light does a disservice to the depth of the beliefs at issue. Such an interpretation also falls prey to the temptation to paint the 1790 s as the fall from grace, the sullied and sordid aftermath of the edenic moment of 1787-1789. Certainly, the rancor of the 1790s was real; the allegiances had hardened, and the threat that ongoing warfare in Europe would engulf the United States added a new level of global consequence to the continuing uncertainty about the Republic's future. And I do not mean to suggest that politics and ideas are separate categories, with "mere” politics bearing no relationship to the realm of ideas. My point is that the partisan din of the 1790s should not trick jaded modern observers into thinking that the source of the

119 See generally Stanley Elkins and Eric McKitrick, The Age of Federalism: The Early American Republic, 1788-1800 (Oxford 1993); David Hackett Fischer, The Revolution of American Conservatism: The Federalist Party in the Era of Jeffersonian Democracy (Harper \& Row 1965).

120 The outlines of this story appeared early. One day before Jefferson's inauguration, James Monroe then Virginia's governor - wrote to the president-elect that the Federalist party "has retired into the judiciary in a strong body where it lives on the treasury, \& cannot therefore be starved out. [W]hile in possession of that ground it can check the popular current which runs against them, \& seize the favorable occasion to promote reaction, w[hi]ch it does not despair of." Monroe to Jefferson, Mar. 3, 1801, 4 DHSC at 720 (cited in note 32).

121 See Turner [Preyer], Federalist Policy and the Judiciary Act of 1801, 22 Wm \& Mary Q at 3 (cited in note 5).

122 Joanne B. Freeman, The Election of 1800: A Study in the Logic of Political Change, 108 Yale L J 1959, 1961, 1990 (1999). 
conflict was political gain or power alone. ${ }^{123}$ Rather, the source of the conflict was political gain and power, as well as ongoing and fundamental disagreement about just what the "federal" in "federal republic" was to mean, and what role the judiciary would play in that federal republic.

The debates that culminated in the passage and repeal of the 1801 act demonstrate the degree to which early-nineteenth-century theories of jurisdiction took on the full weight of the sovereignty discourse of the eighteenth century, transforming questions of political authority in the broadest sense into issues of judicial power and the degree to which the federal and state systems would or would not overlap. By 1801, jurisdiction had replaced sovereignty as the lodestar of American constitutional debate. The 1801 act thus continued the 1789 act's project of adjusting federal judicial structure as a means of adjusting the structure of federalism - the relationship between the states and the general government - itself.

Yet many of the premises underpinning the 1801 act differed markedly from those that informed the 1789 act. One crucial difference concerned the scope of the federal judicial power in the respective acts. As we have seen, the 1789 act took a cautious, even conciliatory, approach to the states' claims to jurisdiction. For example, the federal districts replicated the boundaries of the states rather than asserting new districts that swallowed or subdivided the states; in addition, supporters of the act pointed to its acknowledgment of concurrent state and federal jurisdiction as evidence that the lower federal courts were not intended to supplant the state courts. The drafters of the 1801 act, in contrast, spent little time reassuring the states and instead presented a significantly more robust federal judiciary - both in terms of the number of courts and in the nature of their jurisdiction - with the potential for far greater intrusion into the states. The 1801 act, in other words, combined the colonial impulse to draw lines between levels of authority with the ratification era's focus on the judiciary as the principal axis of that division.

\section{A. $\quad$ Debating the Judiciary Act of 1801.}

Throughout the 1790s, Congress engaged in relatively modest reforms of the federal judiciary, despite complaints from many quarters regarding the 1789 act. The chief criticism centered on the requirement that Supreme Court justices ride circuit, which meant not only fatigue for the justices but also occasional conflicts insofar as a given justice might hear the same case twice, once at the circuit level and once in the Supreme Court. ${ }^{124}$ Following John Adams's December 1799 address to Congress, the members of the Sixth Congress began to consider a comprehensive overhaul. In his address, the president insisted that "a revision and amendment of the judicial system" was

${ }^{123}$ One influential recent study of the political battles of the 1790s and 1800s situates partisan struggle in a broader cultural and ideological context. See Joanne B. Freeman, Affairs of Honor: National Politics in the New Republic (Yale 2001).

124 See Turner [Preyer], Federalist Policy and the Judiciary Act of 1801, 22 Wm \& Mary Q at 5-6 (cited in note 5). 
"indispensably necessary" to "give due effect to the civil administration of Government, and to ensure a just execution of the laws."125 Congress appeared to take Adams's recommendation seriously. In February 1800, a House committee met with justices William Paterson and Bushrod Washington to receive their recommendations for reform. The committee comprised five members, all Federalists: Robert Goodloe Harper of South Carolina; Chauncey Goodrich of Connecticut; James A. Bayard of Delaware, Samuel Sewall of Massachusetts, and John Marshall of Virginia. ${ }^{126}$ Shortly thereafter, on March 11, Harper introduced the committee's draft bill to the House.

The centerpiece of the Harper bill, as it was known, was a proposal to increase the number of federal judicial districts from thirteen to thirty, and the circuit courts from three to nine. ${ }^{127}$ As these numbers suggest, the districts in the Harper bill did not conform to state boundaries; instead, most states were divided into multiple districts. The bill also proposed new names for the districts, given that they could no longer share nomenclature with the state with which they overlapped. The counties of Essex, Suffolk, Norfolk, Middlesex, Bristol, Plymouth, Barnstable, Duke, and Nantucket in Massachusetts were to constitute the district of Boston. The remaining Massachusetts counties (Berkshire, Hampshire, Worcester), meanwhile, would be combined into the district of Warranoch. Virginia's counties were to be divided among the Potowmac, Fluvanna, Kenhawa districts. Rhode Island would not be divided but would constitute the district of Narragansett; similarly, Vermont would constitute the single district of Champlain, although Connecticut's district would be called Connecticut. ${ }^{128}$ As for the nine circuits, each was described according to the districts it comprised:

The first circuit shall consist of the districts of Kennebeck, Merrimac, Boston, and Narragansett; the second, of the districts of Connecticut, Warranock [sic], and Champlain; the third, of the districts of Hudson, Saratoga, and Ontario; the fourth, of the districts of Rariton, Schuylkill, Delware, and Choptank; the fifth, of the districts of Chesapeake, Susquehanna, and Alleganey; the sixth, of the districts of Potomac [sic], Fluvannah [sic], and Kenhawa; the seventh, of the districts of Pamplico, Catawba, and Saluda; the eight, of the districts of Santee, Alatamaha, and Savannah; and the ninth, of the districts of Holston, Cumberland, Ohio, and Rockcastle. ${ }^{129}$

Besides this realignment of the districts and circuits, the bill proposed to expand the circuit courts' jurisdiction over several types of cases, including “all actions and suits,

\footnotetext{
${ }^{125}$ Quoted in 4 DHSC at 284 (cited in note 32).

${ }^{126}$ Unfortunately, no official records of the committee's deliberations have survived.

${ }^{127}$ Harper Judiciary Bill of 1800, §§ 7 \& 10, in id at 312-14.

${ }^{128}$ Id.

${ }^{129}$ Id at 314.
} 
matters or things, cognizable by the judicial authority of the United States, under and by virtue of the constitution thereof," as long as the amount in question was at least one hundred dollars and exclusive jurisdiction was not already vested in the Supreme Court by the Constitution or in the admiralty courts pursuant to the new bill. ${ }^{130}$

Despite the committee's efforts (including John Marshall's "lengthy defence of the new system" on the floor of the House), the Harper bill immediately stirred enormous controversy both inside and outside Congress. ${ }^{131}$ Much of the criticism focused on the provision to increase and rearrange the district courts. Georgia senator Abraham Baldwin, writing to his brother-in-law Joel Barlow (then the American ambassador to Algiers), characterized the Harper bill as intended "to new model the judiciary" and called it "a very broad stroke to draw all the powers to the general government and to do away as far as possible not only state powers, but even boundaries.”132 The Philadelphia Aurora, meanwhile, lambasted the reorganization of the districts, chortling, "instead of calling Jersey by that name the district is to be denominated (alamode de Paris) the department or district of Rariton, and so on throughout the United States!"133 Given the frequency with which Federalists accused the Aurora and other Republican newspapers of "jacobin” sympathies, this critique of the Harper bill as carrying out renaming projects akin to those of revolutionary France's Committee of Public Safety is particularly noteworthy. In a letter to his brother John Quincy Adams, U.S. minister to Prussia, Thomas Boylston Adams despaired of such suspicions but expressed some of his own. "[T]here is an evident reluctance in many gentlemen towards these great national acts, because they tend to strengthen the bonds of union \& give an influence to the general Government, that interferes with their malignant designs," the president's younger son wrote. $^{134}$

Facing this opposition, on March 31 Harper introduced an amended bill in which the number of districts was reduced to 19 and the circuits to six. In the amended bill, the names and boundaries of the district courts followed the names and boundaries of the states (with the exceptions of Massachusetts, New York, Pennsylvania, Virginia, and Tennessee, each of which was divided into two districts). This scaling-back of the federal courts' presence was accompanied, however, by an extension of their jurisdiction. ${ }^{135}$ Pursuant to the amended bill, the circuit courts' jurisdiction would encompass "all cases in law or equity, arising under the constitution and laws of the United States, and treaties made, or which shall be made, under their authority." ${ }^{136}$ The

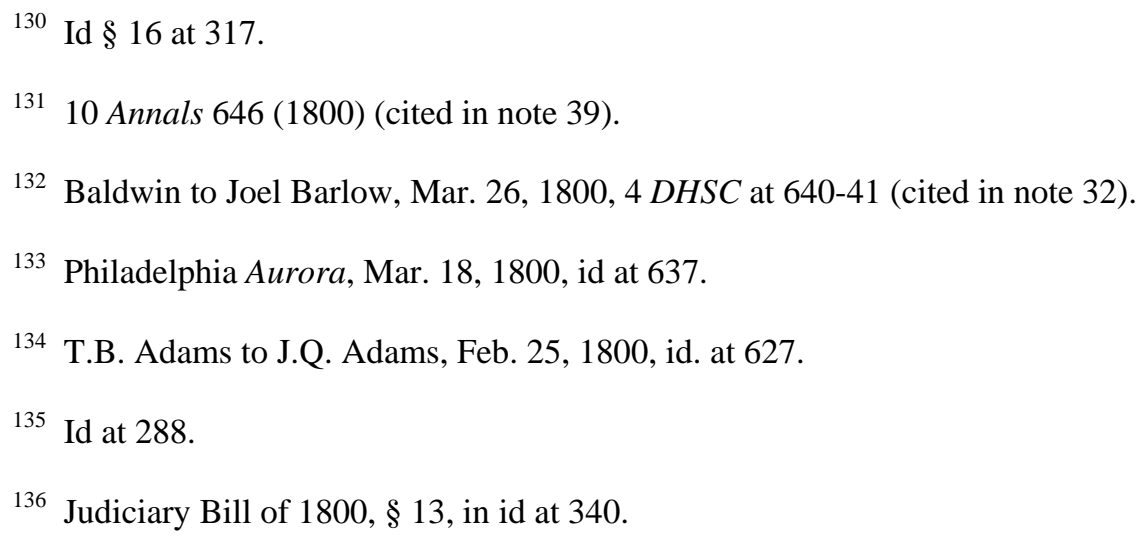


scope of this grant stood in sharp contrast to the 1789 act's grant of original jurisdiction to the circuit courts in, first, "all suits of a civil nature at common law or in equity" in which the amount in controversy is at least five hundred dollars, and the United States is a plaintiff or petitioner, or an alien is a party; and second, diversity suits. ${ }^{137}$ The amended bill's jurisdictional grant was not as broad as that of the original Harper bill, however, which as we have seen proposed expanding the scope of federal jurisdiction to "all actions and suits, matters or things, cognizable by the judicial authority of the United States, under and by virtue of the constitution thereof" - that is, to the full extent of judicial power under Article III. ${ }^{138}$

The amended bill made little progress in the first session of the Sixth Congress. In the second session, however, a new committee - including some Republicans - took up the judiciary question again and presented a substantially similar bill to the full House. ${ }^{139}$ At the beginning of the session, Adams had again pressed for judicial reform in a speech to Congress that Marshall - now secretary of state - had helped prepare. ${ }^{140}$ Following some discussion of the propriety of permitting state courts to exercise jurisdiction over federal cases, the bill passed the House on January 20, 1801, and the Senate on February 7. Titled "An Act to provide for the more convenient organization of the Courts of the United States," the bill became law upon receiving Adams's signature on February 13. The final form of the provision regarding the circuit courts' original jurisdiction closely tracked the language of the amended Harper bill. Section 11 of the act provided " $[t]$ hat the said circuit courts respectively shall have cognizance . . . of all cases in law or equity, arising under the constitution and laws of the United States, and treaties made, or which shall be made, under their authority."141 In addition, the act provided for easier removal of cases from state to federal court. ${ }^{142}$ Four days after the law's enactment, on February 17, the House finally settled the disputed presidential election by electing Jefferson on the thirty-sixth ballot.

As this chronology demonstrates, and as several scholars have noted, the movement that led to the Judiciary Act of 1801 predated the election of 1800 by several months. Thus, as Preyer notes, "the Act was clearly not occasioned by the Republican victory in 1800."143 Indeed, commentators on both sides of the partisan divide had

\footnotetext{
137 Judiciary Act of 1789, § 11.

138 Harper Judiciary Bill of 1800, § 16, in 4 DHSC at 317 (cited in note 32).

139 Id at 289.

140 See Marshall to John Adams, Nov. 17, 1800, in 6 The Papers of John Marshall 11-12 (North Carolina 1990) (Charles F. Hobson, ed).

141 Judiciary Act of 1801, § 11.

142 Id $\S 13$.

143 Turner [Preyer], Federalist Policy and the Judiciary Act of 1801, 22 Wm \& Mary Q at 3 (cited in note 5). See also Linda K. Kerber, Federalists in Dissent: Imagery and Ideology in Jeffersonian America 136
} 
anticipated an attempted expansion of the federal judicial power for some time before the 1801 act came to pass. In August 1799, Jefferson had confided his fears about the expansion of the federal government - in particular, the federal judiciary - in a letter to Edmund Randolph. Specifically, Jefferson worried that the growth of federal courts' jurisdiction would lead to a body of federal common law separate from state law that would become a tool of federal oppression. Jefferson's use of pronouns to refer to the government - and thus to the Federalists - is particularly illuminating:

Of all the doctrines which have ever been broached by the federal government, the novel one, of the common law being in force \& cognizable as an existing law in their courts, is to me the most formidable. All their other assumptions of un-given powers have been in the detail. The bank law, the treaty doctrine, the sedition act, alien act . . . \&c., \&c., have been solitary, unconsequential, timid things, in comparison with the audacious, bare-faced and sweeping pretension to a system of law for the $U \mathrm{~S}$, without the adoption of their legislature, and so infinitely beyond their power to adopt. ${ }^{144}$

For Jefferson, jurisdiction was a mere cover for the spread of substantive federal law, objectionable not only because it could potentially serve as an agent of nationalization but also - and perhaps more important - because such a body of law could not be checked by the people in the states.

Jefferson's democratic critique of the trend toward broader federal jurisdiction finds an echo in the writings of some leading Federalists, who harbored similar but differently directed concerns about the relationship between the people and the federal government. In contrast to Jefferson's claim that the general government was covertly absorbing the powers of the states, and therefore of the people, Federalists such as Hamilton and Sedgwick envisioned the spread of federal power as conducive both to the public good and, not incidentally, to the power of the current government. "An accurate view of the internal situation of the UStates presents many discouraging reflections to the enlightened friends of our Government and country," Hamilton lamented in October 1799. ${ }^{145}$ Despite the "instructive comments afforded by the disastrous \& disgusting scenes of the french Revolution," he observed that "sentiments dangerous to social happiness have not been diminished.", Given this situation, "vigorous measures of

(Cornell 1970) ("Contrary to its subsequent reputation, the Judiciary Act of 1801 had been the subject of a full and responsible debate during the preceding session of Congress, and its terms represented an attempt to correct the inadequacies of the first Judiciary Act of twelve years before.”).

144 Jefferson to Randolph, Aug. 18, 1799, in Thomas Jefferson: Writings 1066 (Library of America 1984) (Merrill D. Peterson, ed) (emphasis added).

145 Hamilton to Jonathan Dayton, Oct.-Nov. 1799, in 25 The Papers of Alexander Hamilton 599 (Columbia 1976) ) (Harold C. Syrett, ed).

146 Id. 
counteraction" were required of the friends of the government, including the "Extension of the Judiciary system" by dividing each state into smaller districts and appointing federal justices of the peace in local areas. ${ }^{147}$ Sedgwick recommended a similar program of extending federal power further into the states. "If the real federal majority can act together much may and ought to be done to give efficiency to the government, and to repress the efforts of the Jacobins against it," he wrote to Rufus King. "We ought to spread out the judicial so as to render the justice of the nation acceptable to the people, to aid national economy, to overawe the licentious, and to punish the guilty."148 And, like Hamilton, Sedgwick noted that these lofty goals also offered more immediate benefits: "[W]e ought, at the same time, that we promote the real happiness \& welfare of the people, to court thereby their favor." 149

These comments from Hamilton and Sedgwick emphasize the nature of the Federalists’ program of expanded federal judicial power. In contrast to Hamilton's earlier acceptance of concurrent powers when writing as Publius in Federalist 32, by 1799 he was no longer attempting to thread the needled of concurrent power while still maintaining a forceful general government. Instead, Hamilton - and Sedgwick as well embraced a vision of federal power that resembled the one that Randolph had struggled to articulate in his report of 1790. That vision in turn owed a debt to the opposition theories that colonists had deployed against parliamentary power in the 1760s and 1770s, according to which each level of the composite imperial government would possess the authority to regulate a defined set of subjects. Common to these early approaches and the views of Hamilton, Sedgwick, and others in the 1790s and 1800s was a belief that the federal and state governments would operate best as parallel powers, each with its own area of competence, with little concurrence or crossover. A decade earlier, however, as we have seen, many commentators had emphasized the opposite, insisting that concurrent powers of legislation as well as adjudication were inevitable and perhaps even desirable in the new federal republic.

The language of the two judiciary acts illustrates this difference in emphasis. While the 1789 act makes multiple references to concurrent state- and federal-court jurisdiction, the only mention of concurrence in the 1801 act concerns the concurrent jurisdiction of district and circuit courts with respect to bankruptcy proceedings. ${ }^{150}$ Similarly, contrast the apparatus of inferior federal courts established by the 1789 act with that of the 1801 act. While the drafters of the 1789 act took pains to make the new districts track state boundaries as much as possible, thereby avoiding the suggestion that

\footnotetext{
147 Id at 601.

148 Sedgwick to King, Nov. 15, 1799, in 3 The Life and Correspondence of Rufus King 145 (G.P. Putnam’s Sons 1896) (Charles R. King, ed).

149 Id at 147. On Hamilton and ideas of the public good, see Cecelia Kenyon, Alexander Hamilton: Rousseau of the Right, 73 Polit Sci Q 161 (1958).

150 Compare Judiciary Act of 1789, §§ 9, 11, with Judiciary Act of 1801, § 12.
} 
the general government was working to subsume the states within its own artificial boundaries and structures, the drafters of the 1801 act broke the states down into smaller, more administrable districts, showing little concern for the integrity of the states as they did so. Indeed, the Harper bill provides an even more striking example of this apparent lack of respect for state boundaries, selecting regional, geographic, or Indian names for the districts rather than adopt the titles of the states. Thus, the goal of separating the levels of government - with the dual effects of undoing past blurring and asserting national power - increasingly informed the Federalists' federalizing policy after 1789. And they viewed the expansion of the federal courts' general federal question jurisdiction, which had begun with the Randolph and Harper proposals and culminated in the "arising under" jurisdiction of the 1801 act, as the key to this separation.

\section{B. Repeal.}

Of course, the Federalists did not long enjoy the fruits of their plan. Upon the election of Jefferson by the House of Representatives in February 1801, many observers predicted the course of subsequent events. The events leading up to the repeal of the Judiciary Act of 1801 are well known and do not require extensive description here. ${ }^{151}$ The 1801 act was repealed on March 8, 1802, by a repealing act ${ }^{152}$ that "annulled the 1801 act's broad grant of federal question jurisdiction and discarded the newly created circuit courts, forcing the Supreme Court justices again to ride circuit and act as circuit judges." 153 In 1803, six days after handing down the decision in Marbury, the Supreme Court upheld the validity of the repealing act. ${ }^{154}$

In the waning days of the Adams administration, as the president filled the sixteen new circuit judgeships that the act had created $^{155}$, murmurings of repeal had already begun to surface. ${ }^{156}$ In his first annual message to Congress, Jefferson said, without really saying, the obvious. "The Judiciary system of the United States, and especially that portion of it recently erected, will, of course, present itself to the contemplation of Congress," the president said, noting that he had already requested an account of all the

${ }^{151}$ On the repeal of the act, see generally George Lee Haskins and Herbert A. Johnson, Foundations of Power: John Marshall, 1801-15 (Macmillan 1981) (especially chapters 4 and 5); Kathryn Turner [Preyer], The Midnight Judges, 109 U Pa L Rev 494 (1961).

152 "An Act to repeal certain acts respecting the organization of the Courts of the United States; and for other purposes,” March 8, 1801, 2 Stat. 132.

1534 DHSC at 294-95 (cited in note 32).

154 Stuart v Laird, 1 Cranch 299 (1803). Despite the repeal, however, at least one case brought pursuant to the 1801 act's grant of federal question jurisdiction managed to survive the repeal. See Wythe Holt, The First Federal Question Case, 3 Law and Hist Rev 169 (1985).

155 These were the so-called “midnight judges.” See Turner [Preyer], The Midnight Judges, 109 U Pa L Rev at 495 (cited in note 151).

156 See 4 DHSC at 295 (cited in note 32). 
cases that had been decided since 1789 and of the number of cases that had been pending when the 1801 act took effect. ${ }^{157}$ The act of 1801 had established six new circuit courts and seven new district courts. ${ }^{158}$ Jefferson and his associates insisted that the Federalists had erected this apparatus as a means of entrenching their power in the face of popular opposition. ${ }^{159}$ In their view, concurrence was not a bone to be thrown - or not - to the cowering states at the pleasure of a mighty federal government, but quite the opposite: a gesture of goodwill on the part of the states as they shared a measure of their plenary power, their sovereignty, with the general government.

Hamilton, writing as "Lucius Crassus" in the New-York Evening Post, sneered at Jefferson's attempt to prove that the new courts were unnecessary. "No bad thermometer of the capacity of our Chief Magistrate for government is furnished by the rule which he offers for judging of the utility of the Federal Courts,” Hamilton said of Jefferson's plan to tally the number of federal-court cases decided as a means of assessing the need for additional courts. "There is hardly any stronger symptom of a pigmy mind, than a propensity to allow greater weight to secondary than to primary considerations.”160 Hamilton and his allies contended that expanding the federal judicial power was the best solution to the problem of multiple authorities, the problem of imperium in imperio, that had dogged the republic since before its founding. In an address to the New York City bar shortly before the repeal of the 1801 act, Hamilton warned of the consequences that he feared would follow. According to a newspaper report,

He declared in the most emphatic manner, that if the bill for the repeal passed, and the independence of the Judiciary was destroyed, the constitution was but a shadow, and we should, e'er long, be divided into separate confederacies, turning our arms against each. ${ }^{161}$

"Separate confederacies, turning our arms against each" - the famously eloquent Hamilton appears to have selected his words carefully to elicit a response from his audience. But Hamilton's choice of the language of confederation at this moment reveals more than simply rhetorical talents. For many observers in the early years of the nineteenth century, the murky abstraction of Article III’s “judicial power of the United

157 Jefferson, First Annual Message to Congress, Dec. 8, 1801, in 25 The Papers of Alexander Hamilton at 448 n.1 (cited in note 144).

158 Id at 477 n.4.

159 Some Federalists, such as Gouverneur Morris, agreed. But Morris took a more sympathetic view of his colleagues' strategy, observing, "They are about to experience a heavy gale of adverse wind; can they be blamed for casting many anchors to hold their ship through the storm?” Morris to Robert R. Livingston, Feb. 20, 1801, in 3 The Life of Gouverneur Morris 153-54 (Gray \& Bowen 1832) (Jared Sparks, ed).

160 [Hamilton], “The Examination No. V,” New-York Evening Post, Dec. 29, 1801, in id at 477.

161 Hamilton, "Remarks on the Repeal of the Judiciary Act," The New-York Gazette \& General Advertiser, Feb. 13, 1802, in id at 523. 
States" had taken shape only through the institutions of the courts themselves, and only through the device of federal jurisdiction. The years between 1789 and 1802 saw a constant drive to reshape and reconfigure the courts and their jurisdiction, in a period of institutional transformation that was unique to the judiciary. Interestingly, the early Republic witnessed few debates of similar scale regarding the meaning and form of the legislative or executive powers. The language of Article III, combined with the Madisonian compromise, had deliberately left a lacuna in the constitutional structure. By choosing not to fill that gap at Philadelphia, the drafters of the Constitution had ensured that any institution that eventually did fill it would always been seen as provisional, as an attempt but not necessarily a complete solution. The gap was visible from the beginning and would remain so, despite contemporaries' efforts to fill it - with the 1789 act, with the Harper bills, with the 1801 act, with the 1802 repealing act. In some sense, then, the judiciary of any particular era might always appear to its contemporaries as nothing more than "a new wheel ... introduced into the federal machine to which the union was before a stranger, and which is not necessary to its genuine motives."162

\section{Conclusion.}

By 1789, the concept of jurisdiction had become one of the principal contested terrains of constitutional discourse. Instead of the emphasis on the legislature that had fascinated colonial and Revolutionary-era commentators, Americans of the ratification period and the early Republic devoted substantial thought to the structure of the judiciary. The lines of judicial authority thus replaced sovereignty as the great mystery to be unraveled by lawyers, politicians, and thinkers. Yet contemporaries' normative conception of jurisdiction was not stable throughout the period of the early Republic; rather, conflicting visions of jurisdiction - specifically, federal-court jurisdiction collided and shifted throughout the period between the passage of the Judiciary Act of 1789 and the repeal of the Judiciary Act of 1801 in 1802.

The 1801 act must be understood not as an outlier but on its own terms, as among other things - an attempt by Federalists to install a particular version of small-f federalism in the Constitution. That small-f federalism built on theories that colonial commentators had developed beginning in the 1760s, during the struggle with the British Empire. Colonial spokespeople had argued for a system of divided authority in which power was allocated along subject-matter lines, allowing for multiple levels of government to exist in the same system while each exercising a sovereignty defined by the subject of the regulation in question. In the 1801 act, unlike the 1789 act, Federalists sought to return to this idea of subject-matter jurisdiction by establishing broad federal jurisdiction over cases arising under the Constitution, the laws of the United States, and treaties made under their authority. This subject-matter focus was necessarily limited by the Supremacy Clause, which explicitly contemplated some interaction between state judges and federal law and therefore precluded all federal questions from being vested exclusively in federal courts. Yet the Federalists succeeded briefly, most notably by broadening "arising under" jurisdiction and easing the requirements for removal of cases from state to federal court. The election of 1800 and the ensuing repeal of the 1801 act,

162 “A Citizen,” Dunlap’s American Daily Advertiser (Philadelphia), Dec. 20, 1791. 
however, spelled the demise of this idea of jurisdiction and the return of the type of concurrence and overlap that had characterized the system set up by the 1789 act. After 1801, Jeffersonian Americans pulled back from the federal idea that British North Americans had developed in the imperial crisis of several decades earlier. One of the main impulses that had driven early American federalism thus faded after 1802. The fate of Federalism, therefore, fundamentally altered the landscape of federalism.

My goal has in some sense been to bring the 1801 act back into the mainstream of American constitutional history. Admittedly, this is something of a difficult task, owing to the act's truncated lifespan and to scholars' tendency to treat it as an anomaly, the result of a sudden burst of partisan fervor that disturbed the otherwise smooth unfolding of the federal judicial power. But that is precisely why this story matters. By demonstrating that one of the supposed modern endpoints of the teleological account of constitutional history - general federal question jurisdiction - was actually achieved for a brief moment in 1801, and that that achievement can be tied back to colonial ideas of the proper division of authority in a compound government, this account suggests that many ostensibly modern currents in constitutional thought are in fact recycled from earlier debates, and that older ideas can remain compelling in vastly changed circumstances from their original ones. 
Readers with comments may address them to:

Professor Alison L. LaCroix

University of Chicago Law School

1111 East 60th Street

Chicago, IL 60637

lacroix@uchicago.edu 


\section{The University of Chicago Law School Public Law and Legal Theory Working Paper Series}

For a listing of papers 1-99 please go to http://www.law.uchicago.edu/academics/publiclaw/1-99.html

100. Mary Anne Case, Pets or Meat (August 2005)

101. Adam Samaha, Executive Exposure: Government Secrets, Constitutional Law, and Platforms for Judicial Intervention (August 2005, revised November 2005)

102. Jason J. Czarnezki and William K. Ford, The Phantom Philosophy? An Empirical Investigation of Legal Interpretation (August 2005)

103. Adrian Vermeule, Absolute Voting Rules (August 2005)

104. Eric A. Posner and Adrian Vermeule, Emergencies and Democratic Failure (August 2005)

105. Adrian Vermeule, Reparations as Rough Justice (September 2005)

106. Arthur J. Jacobson and John P. McCormick, The Business of Business Is Democracy (September 2005)

107. Tracey Meares and Kelsi Brown Corkran, When 2 or 3 Come Together (October 2005)

108. Adrian Vermeule, Political Constraints on Supreme Court Reform (October 2005)

109. Lior Jacob Strahilevitz, Information Asymmetries and the Rights to Exclude (November 2005)

110. Cass R. Sunstein, Fast, Frugal and (Sometimes) Wrong (November 2005)

111. Cass R. Sunstein, Justice Breyer's Democratic Pragmatism (November 2005)

112. Adam M. Samaha, Endorsement Retires: From Religious Symbols to Anti-Sorting Principles (November 2005)

113. Adam M. Samaha, Undue Process: Congressional Referral and Judicial Resistance in the Schiavo Controversy (November 2005)

114. Bernard E. Harcourt, Should We Aggregate Mental Hospitalization and Prison Population Rates in Empirical Research on the Relationship between Incarceration and Crime, Unemployment, Poverty, and Other Social Indicators? On the Continuity of Spatial Exclusion and Confinement in Twentieth Century United States (January 2006)

115. Elizabeth Garrett and Adrian Vermeule, Transparency in the Budget Process (January 2006)

116. Cass R. Sunstein, Burkean Minimalism (January 2006)

117. Stephanos Bibas, Transparency and Participation in Criminal Procedure (February 2006)

118. Douglas G. Lichtman, Captive Audiences and the First Amendment (February 2006)

119. Eric A. Posner and Cass R. Sunstein, The Law of Other States (March 2006)

120. Jeff Leslie and Cass R. Sunstein, Animal Rights without Controversy (March 2006)

121. Adrian Vermeule, The Delegation Lottery (March 2006)

122. Adrian Vermeule, Self-Defeating Proposals: Ackerman on Emergency Powers (March 2006)

123. Bernard E. Harcourt, Muslim Profiles Post 9/11: Is Racial Profiling an Effective Counterterrorist Measure and Does It Violate the Right to Be Free from Discrimination? (March 2006)

124. Christine Jolls and Cass R. Sunstein, The Law of Implicit Bias (April 2006)

125. Lior Strahilevitz, “How’s My Driving?” for Everyone (and Everything?) (April 2006)

126. Jack Goldsmith and Eric A. Posner, The New International Law Scholarship (May 2006)

127. Eric A. Posner and John Yoo, International Law and the Rise of China (May 2006)

128. Eric A. Posner and Cass R. Sunstein, Chevronizing Foreign Relations Law (May 2006)

129. Jacob E. Gersen and Adrian Vermeule, Chevron as a Voting Rule (June 2006)

130. Jacob E. Gersen, Temporary Legislation (June 2006)

131. Adam B. Cox, Designing Redistricting Institutions (June 2006) 
132. Adam B. Cox, The Temporal Dimension of Voting Rights (July 2006)

133. Curtis A. Bradley and Eric A. Posner, Presidential Signing Statements and Executive Power (July 2006)

134. Cass R. Sunstein, Clear Statement Principles and National Security: Hamdan and Beyond (July 2006)

135. Cass R. Sunstein, Of Snakes and Butterflies: A Reply (August 2006)

136. Cass R. Sunstein, Montreal versus Kyoto: A Tale of Two Protocols (September 2006)

137. Douglas Lichtman, Irreparable Benefits (September 2006)

138. Adam M. Samaha, Undue Process (September 2006)

139. Eric A. Posner and Adrian Vermeule, The Credible Executive (September 2006)

140. Adam B. Cox and Eric A. Posner, The Second-Order Structure of Immigration Law (November 2006)

141. Eric A. Posner, The International Protection of Cultural Property: Some Skeptical Observations (November 2006)

142. Bernard E. Harcourt and Jens Ludwig, Reefer Madness: Broken Windows Policing and Misdemeanor Marijuana Arrests in New York City, 1989-2000 (December 2006)

143. Bernard E. Harcourt, Embracing Chance: Post-Modern Meditations on Punishment (December 2006)

144. Cass R. Sunstein, Second-Order Perfectionism (December 2006)

145. Wayne Hsiung and Cass R. Sunstein, Climate Change and Animals (January 2007)

146. Cass R. Sunstein, Deliberating Groups versus Prediction Markets (or Hayek's Challenge to Habermas) (January 2007)

147. Cass R. Sunstein, Incompletely Theorized Agreements in Constitutional Law (January 2007)

148. Eric A. Posner, Climate Change and Human Rights Litigation: A Critical Appraisal (January 2007)

149. Cass R. Sunstein, Cost-Benefit Analysis without Analyzing Costs or Benefits: Reasonable Accommodation, Balancing, and Stigmatic Harms (January 2007)

150. Cass R. Sunstein, Willingness to Pay versus Welfare (January 2007)

151. Cass R. Sunstein, If People Would Be Outraged by Their Rulings, Should Judges Care? (February 2007)

152. Bernard E. Harcourt, Judge Richard Posner on Civil Liberties: Pragmatic Authoritarian Libertarian (March 2007)

153. Eugene Kontorovich, What Standing Is Good For (March 2007)

154. Eugene Kontorovich, Inefficient Customs in International Law (March 2007)

155. Bernard E. Harcourt, From the Asylum to the Prison: Rethinking the Incarceration Revolution. Part II: State Level Analysis (March 2007)

156. Bernard E. Harcourt, An Answer to the Question: "What Is Poststructuralism?” (March 2007)

157. Cass R. Sunstein, Backlash’s Travels (March 2007)

158. Cass R. Sunstein, Due Process Traditionalism (March 2007)

159. Adam B. Cox and Thomas J. Miles, Judging the Voting Rights Act (March 2007)

160. Jonathan F. Mitchell, Apprendi’s Domain (April 2007)

161. Jacob E. Gersen, Overlapping and Underlapping Jurisdiction in Administrative Law (April 2007)

162. Eric A. Posner and Cass R. Sunstein, On Learning from Others (April 2007)

163. Eric A. Posner and Adrian Vermeule, Originalism and Emergencies: A Reply to Lawson (April 2007)

164. Cass R. Sunstein, Illusory Losses (April 2007)

165. Josh Bowers, Punishing the Innocent (April 2007)

166. Adam M. Samaha, What Good Is the Social Model of Disability? (May 2007) 
167. Cass R. Sunstein, On the Tension between Sex Equality and Religious Freedom (June 2007)

168. Jacob E. Gersen, Legislative Rules Revisited (June 2007)

169. Josh Bowers, Grassroots Plea Bargaining (June 2007)

170. Julie Roin, Can the Income Tax Be Saved? The Promise and Pitfalls of Unitary Formulary Apportionment (April 2007)

171. Daniel Kahneman and Cass R. Sunstein, Indignation: Psychology, Politics, Law (July 2007)

172. Jacob E. Gersen and Eric A. Posner, Timing Rules and Legal Institutions (July 2007)

173. Eric A. Posner and Adrian Vermeule, Constitutional Showdowns (July 2007)

174. Lior Jacob Strahilevitz, Privacy versus Antidiscrimination (July 2007)

175. Bernard E. Harcourt, A Reader's Companion to Against Prediction: A Reply to Ariela Gross, Yoram Margalioth and Yoav Sapir on Economic Modeling, Selective Incapacitation, Governmentality, and Race (July 2007)

176. Cass R. Sunstein, The Complex Climate Change Incentives of China and the United States (August 2007)

177. Eric A. Posner an Cass R. Sunstein, Climate Change Justice (August 2007)

178. Jonathan Remy Nash, Standing and the Precautionary Principle (August 2007)

179. William Meadow and Cass R. Sunstein, Causation in Tort: General Populations vs. Individual Cases (August 2007)

180. Josh Bowers, Contraindicated Drug Courts (August 2007)

181. Timur Kuran and Cass R. Sunstein, Availability Cascades and Risk Regulation (September 2007)

182. Shyamkrishna Balganesh, "Demystifying the Right to Exclude: Of Property, Inviolability, and Automatic Injunctions" (September 2007)

183. Robin Effron, Event Jurisdiction and Protective Coordination: Lessons from September 11th Litigation (October 2007)

184. Richard H. McAdams and Janice Nadler, Coordinating in the Shadow of hte Law: Two Contextualized Tests (October 2007)

185. Richard H. McAdams, Reforming Entrapment Doctrine in United States v. Hollingsworth (October 2007)

186. M. Todd Henderson, From Seriatim to Consensus and Back Again: A Theory of Dissent (October 2007)

187. Jonathan R. Nash and Rafael I. Pardo, An Empirical Investigation into Appellate Structure and the Perceived Quality of Appellate Review (October 2007)

188. Thomas J. Miles and Cass R. Sunstein, The Real World of Arbitrariness Review (November 2007)

189. Richard H. McAdams, The Economic Costs of Inequality (November 2007)

190. Lior Jacob Strahilevitz, Reputation Nation: Law in an Era of Ubiquitous Personal Information (November 2007)

191. Thomas J. Miles and Cass R. Sunstein, The New Legal Realism (December 2007)

192. Jonathan Nash, Economic Efficiency versus Public Choice: The Case of Property Rights in Road Traffic Management (December 2007)

193. Edward L. Glaeser and Cass R. Sunstein, Extremism and Social Learning (December 2007)

194. Adam M. Samaha, Dead Hand Arguments and Constitutional Interpretation (January 2008)

195. Eric A. Posner, Does Political Bias in the Judiciary Matter?: Implications of Judicial Bias Studies for Legal and Constitutional Reform (January 2008)

196. Jacob E. Gersen and Anne Joseph O’Connell, Deadlines in Administrative Law (January 2008)

197. Alison L. LaCroix, The New Wheel in the Federal Machine: From Sovereignty to Jurisdiction in the Early Republic (January 2008) 